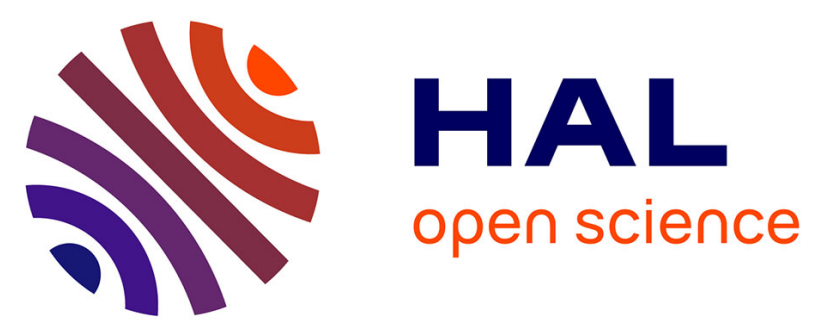

\title{
Novel CDTA-based, Bifunctional Chelators for Stable and Inert Mn II Complexation: Synthesis and Physicochemical Characterization
}

\author{
Christian Vanasschen, Enikö Molnár, Gyula Tircso, Ferenc Kálmán, Éva \\ Tóth, Marie Brandt, Heinz H Coenen, Bernd Neumaier
}

\section{To cite this version:}

Christian Vanasschen, Enikö Molnár, Gyula Tircso, Ferenc Kálmán, Éva Tóth, et al.. Novel CDTA-based, Bifunctional Chelators for Stable and Inert Mn II Complexation: Synthesis and Physicochemical Characterization. Inorganic Chemistry, 2017, 56 (14), pp.7746 - 7760. 10.1021/acs.inorgchem.7b00460 . hal-02572209

\section{HAL Id: hal-02572209 \\ https://hal.science/hal-02572209}

Submitted on 13 May 2020

HAL is a multi-disciplinary open access archive for the deposit and dissemination of scientific research documents, whether they are published or not. The documents may come from teaching and research institutions in France or abroad, or from public or private research centers.
L'archive ouverte pluridisciplinaire HAL, est destinée au dépôt et à la diffusion de documents scientifiques de niveau recherche, publiés ou non, émanant des établissements d'enseignement et de recherche français ou étrangers, des laboratoires publics ou privés. 
Novel CDTA-based, bifunctional chelators for stable and inert $\mathrm{Mn}^{\mathrm{II}}$ complexation: Synthesis and physico-chemical characterization

Christian Vanasschen ${ }^{1 *}$, Enikő Molnár ${ }^{2}$, Gyula Tircsó ${ }^{2 *}$, Ferenc K. Kálmán ${ }^{2,3,4}$, Éva Tóth ${ }^{3}$, Marie Brandt $^{1}$, Heinz H. Coenen ${ }^{1}$, Bernd Neumaier ${ }^{1}$

${ }^{1}$ Institut für Neurowissenschaften und Medizin, INM-5: Nuklearchemie, Forschungszentrum Jülich GmbH, Jülich, Germany

${ }^{2}$ Department of Inorganic and Analytical Chemistry, Faculty of Science and Technology, University of Debrecen, Debrecen, Egyetem tér 1, H-4010, Hungary

${ }^{3}$ Centre de Biophysique Moléculaire, CNRS, Université d'Orléans, rue Charles Sadron, 45071 Orléans, Cedex 2, France

${ }^{4}$ Le Studium, Loire Valley Institute for Advanced Studies, 1 Rue Dupanloup, 45000 Orléans, France

Corresponding Authors

*E-mail: c.vanasschen@fz-juelich.de

*E-mail: gyula.tircso@science.unideb.hu 


\section{Abstract}

Seeking for $\mathrm{Mn}^{\mathrm{II}}$ MR and PET/MR imaging agents with optimal balance between thermodynamic stability, kinetic inertness and relaxivity, two novel bifunctional $\mathrm{Mn}^{\mathrm{II}}$ chelators (BFMnCs) based on CDTA (trans-1,2-diaminocyclohexane- $\mathrm{N}, \mathrm{N}, \mathrm{N}^{\prime}, \mathrm{N}^{\prime}$-tetraacetic acid) were synthesized. A 6-step synthesis, involving the build-up of a functionalized trans-1,2-diaminocyclohexane core, provided CuAAC-reactive $\mathbf{6 a}$ and $\mathbf{6 b}$ bearing an alkyne or azide substituent on the cyclohexane ring, respectively $\left(\mathrm{CuAAC}=\mathrm{Cu}^{\mathrm{I}}\right.$-catalyzed azide-alkyne 1,3-dipolar cycloaddition). Thermodynamic, kinetic and relaxometric studies were performed with 4-HET-CDTA (8a) as "model chelator", synthesized in 2 steps from 6a. The protonation constants revealed that $\mathbf{8 a}$ is slightly less basic than CDTA and forms a $\mathrm{Mn}^{\mathrm{II}}$ complex of marginally lower thermodynamic stability (log $K_{\mathrm{MnL}}=13.80 \mathrm{vs}$. 14.32, respectively), while the conditional stability constant is almost identical for both chelates (pMn $=8.62$ vs. 8.68, respectively). Kinetic assessment of the $\mathrm{Cu}^{\mathrm{II}}$-mediated transmetallation of [Mn(4HET-CDTA)] ${ }^{2-}$ showed that proton-assisted complex dissociation is slightly slower than for $[\mathrm{Mn}(\mathrm{CDTA})]^{2-}\left(k_{1}=297\right.$ vs. $400 \mathrm{M}^{-1} \mathrm{~s}^{-1}$, respectively). Importantly, the dissociation half-life near physiological conditions ( $\mathrm{pH} 7.4,25{ }^{\circ} \mathrm{C}$ ) underlined that $[\mathrm{Mn}(4-\mathrm{HET}-\mathrm{CDTA})]^{2-}$ is $\approx 35 \%$ more inert ( $t_{1 / 2}=16.2$ vs. $12.1 \mathrm{~h}$, respectively). Those findings may be accounted for by a combination of reduced basicity and increased rigidity of the ligand. Analysis of the ${ }^{17} \mathrm{O}$ NMR and ${ }^{1} \mathrm{H}$ NMRD data attributed the high relaxivity of $[\mathrm{Mn}(4-\mathrm{HET}-\mathrm{CDTA})]^{2-}\left(r_{1}=4.56 \mathrm{mM}^{-1} \mathrm{~s}^{-1}\right.$ vs. $3.65 \mathrm{mM}^{-1} \mathrm{~s}^{-1}$ for $[\mathrm{Mn}(\mathrm{CDTA})]^{2-}$; $\left.20 \mathrm{MHz}, 25^{\circ} \mathrm{C}\right)$ to slower rotational dynamics $\left(\tau_{\mathrm{R}}^{298}=105 \mathrm{ps}\right)$. Additionally, the fast water-exchange of the complex correlates well with the value reported for $[\operatorname{Mn}(\mathrm{CDTA})]^{2-}\left(k_{\mathrm{ex}}{ }^{298}=17.6 \times 10^{7}\right.$ vs. $14.0 \mathrm{x}$ $10^{7} \mathrm{~s}^{-1}$, respectively). Given the exquisite compromise between thermodynamic stability, kinetic inertness and relaxivity achieved by $[\mathrm{Mn}(4-\mathrm{HET}-\mathrm{CDTA})]^{2-}$, appropriately designed CuAACconjugates of $\mathbf{6 a / 6 b}$ are promising precursors for the preparation of targeted, bioresponsive or high relaxivity manganese-based PET/MR tracers $\left({ }^{52 g / 55} \mathrm{Mn}^{\mathrm{II}}\right)$ and MR contrast agents $\left(\mathrm{Mn}^{\mathrm{II}}\right)$.

\section{Introduction}

In recent years, research on contrast agents (CAs) for magnetic resonance imaging (MRI) increasingly focused on paramagnetic $\mathrm{Mn}^{\mathrm{II}}$ complexes as alternatives to the well-established $\mathrm{Gd}^{\mathrm{III}}$ chelates routinely used in the clinical setting. ${ }^{1-4}$ As a matter of fact, some $\mathrm{Gd}^{\mathrm{III}} \mathrm{CAs}$ have been associated with tissue-deposition of toxic (free) gadolinium in patients suffering from chronic kidney disease (CKD), which causes nephrogenic systemic fibrosis (NSF), a potentially lethal fibrotic disease of the skin and internal organs. ${ }^{5,6}$ Very recently, a review by Kanal and Tweedle summarized several studies even highlighting the deposition of $\mathrm{Gd}^{\mathrm{III}}$ in the brain of non-renally impaired patients, further questioning the use of certain marketed Gd-based CAs. ${ }^{7}$

Compared to $\mathrm{Gd}^{\mathrm{III}}, \mathrm{Mn}^{\mathrm{II}}$ has the major advantage of being essential to the human body as trace amounts are involved in several enzymatic as well as metabolic processes in vivo. ${ }^{8}$ In addition, the 
$\mathrm{Mn}^{\mathrm{II}}$ ion possesses all the requisite physical properties for $T_{1}$-weighted MR applications: fast water exchange kinetics, slow longitudinal electronic relaxation and a high spin quantum number $(S=5 / 2){ }^{1}$ Despite the biogenic nature of $\mathrm{Mn}^{\mathrm{II}}$, the relatively high paramagnetic metal concentrations typically used in MRI (0.05 - $\left.0.30 \mathrm{mmol} . \mathrm{kg}^{-1}\right)$ require the cation to be chelated within a thermodynamically stable and kinetically inert complex to be used as a contrast agent. However, to allow for efficient in vivo imaging, manganese chelates should not only fulfill thermodynamic and kinetic stability requirements but also exhibit high relaxivity values. Relaxivity $\left(r_{1}\right)$ is a measure of CA efficiency and is defined as the enhancement of the $T_{1}$ relaxation rate of water protons induced by a millimolar CA concentration $\left(r_{1}=\Delta\left(1 / T_{1}\right) /[\mathrm{CA}]\right.$ in $\left.\mathrm{mM}^{-1} \mathrm{~s}^{-1}\right)$; the higher the relaxivity, the higher the positive contrast on $T_{1}$-weighted MR images. Importantly, to attain elevated $r_{1}$ values, the paramagnetic complex needs to possess at least one water molecule coordinated to the central metal ion (hydration number, $q$, should be $\geq 1)$. Taking into account the coordination number $(\mathrm{CN})$ of $\mathrm{Mn}^{\mathrm{II}}(\mathrm{CN}=6-7)$, the chelator of choice should therefore contain a maximum of six donor groups in order to allow the $\mathrm{Mn}^{\mathrm{II}}$ ion to carry a water coligand. Unfortunately, recent literature has shown that applying this rationale does not guarantee the obtained chelates to fulfill both stability/inertness and relaxivity criteria (in this manuscript, the terms lability/inertness describe chelate dissociation kinetics rather than solvent exchange kinetics). For example, [Mn(NOTA)]- (NOTA = 1,4,7-triazacyclononane-1,4,7-triacetic acid, see Chart 1) was shown to be exceptionally stable thermodynamically as well as kinetically inert but the complex does not contain a coordinated water molecule $(q=0)$ despite the hexadentate nature of the chelator. ${ }^{9}$ On the other hand, open-chain hexacoordinate [Mn(EDTA) $]^{2-}$ combines $q=1$ and a good thermodynamic stability with extremely high kinetic lability. ${ }^{10,11}$ Notably, the case of the cyclen derivatives 1,4-DO2A and 1,7-DO2A (denticity = 6; cyclen = 1,4,7,10-tetraazacyclododecane; Chart 1) appears particularly remarkable. Although both isomers form $\mathrm{Mn}^{\mathrm{II}}$ complexes that display similarly high stability ${ }^{10}$ and inertness, ${ }^{12}$ the position of the pendant acetate arms has a striking impact on the hydration number as $q=0$ for [Mn(1,7-DO2A)] versus $q=0.9$ for [Mn(1,4-DO2A)] (the latter exists as a mixture of two species; i.e. $\approx 87 \%$ having $q=1$ and $\approx 13 \% q=0$ ). ${ }^{10}$ Those three examples illustrate that the design of $\mathrm{Mn}^{\mathrm{II}}$-based CAs suitable for in vivo application, i.e. associating sufficient thermodynamic stability with considerable kinetic inertness and good $T_{1}$-contrast enhancement, is a highly challenging task. 

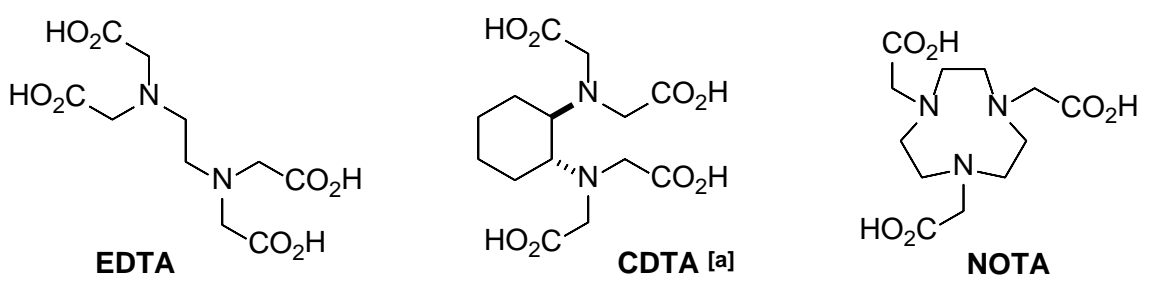

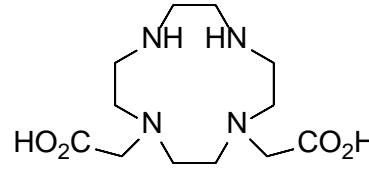

1,4-DO2A

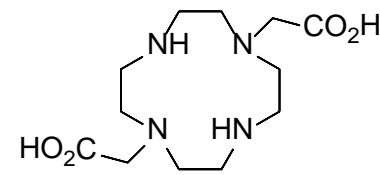

1,7-DO2A

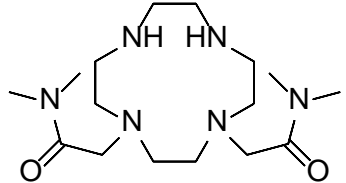

1,4-DO2AM

Chart 1. Structures of the ligands discussed in this work.

[a] Unless otherwise stated, CDTA will always refer to the trans-isomer of 1,2-diaminocyclohexane- $N, N, N^{\prime}, N^{\prime}$ tetraacetic acid in this paper.

In 2012, Kálmán and Tircsó assessed the kinetic inertness of several $\mathrm{Mn}^{\mathrm{II}}$ complexes of openchain EDTA derivatives and reported their dissociation half-life under physiological conditions, $t_{1 / 2}$ ( $\mathrm{pH}=7.4) .{ }^{11}, 13$ The main finding of this study was that the rigidifying effect of the cyclohexyl bridge of CDTA (trans-1,2-diaminocyclohexane- $N, N, N^{\prime}, N^{\prime}$-tetraacetic acid, Chart 1) results in a marked increase in kinetic inertness of the corresponding $\mathrm{Mn}^{\mathrm{II}}$ chelate when compared to EDTA, having a flexible ethylene bridge $\left(t_{1 / 2}=12 \mathrm{~h}\right.$ for $[\mathrm{Mn}(\mathrm{CDTA})]^{2-}$ versus $\approx 5 \mathrm{~min}$ for $\left.[\mathrm{Mn}(\mathrm{EDTA})]^{2-}\right)$. Also taking into account the monohydrated nature ( $q=1,{ }^{14}$ which results in a relaxivity value of $r_{1}=3.65 \mathrm{mM}^{-1} \mathrm{~s}^{-1}$ at $20 \mathrm{MHz}$ and $\left.25^{\circ} \mathrm{C}\right)$, as well as the good thermodynamic stability of $[\mathrm{Mn}(\mathrm{CDTA})]^{2-}\left(\log K_{\mathrm{ML}}=\right.$ 14.32), it appears that this manganese complex displays all the required features for in vivo MR imaging. ${ }^{11}$

Our interest in $\mathrm{Mn}^{\mathrm{II}}$-based CAs has been induced by the capability to produce the positronemitting radionuclide manganese-52g $\left({ }^{52 \mathrm{~g}} \mathrm{Mn}\right)$ which has promising decay properties for PET imaging $\left(\mathrm{t}_{1 / 2}=5.6 \mathrm{~d}, \beta^{+}\right.$-decay intensity: 29.6\%, max. $\beta^{+}$-energy: $\left.575 \mathrm{keV}\right) .{ }^{15,16}$ We have recently shown that radiolabeling CDTA with an isotopic ${ }^{52 g / 55} \mathrm{Mn}$ mixture (or c.a. ${ }^{52 \mathrm{gn}}$, c.a. = carrier-added) provides the corresponding bimodal PET/MR tracer with ease. ${ }^{17}$ This technique allows overcoming the major hurdle to the design of PET/MR probes, i.e. the huge sensitivity difference between both techniques, which necessitates nanomolar versus millimolar concentration of PET and MR reporter molecules, respectively. Additionally, radiolabeling with c.a. ${ }^{52} \mathrm{Mn}$ guarantees that both reporter molecules are chemically identical, thereby ensuring equivalent in vivo behavior. Dual-modal PET/MR probes not only allow to combine the exquisite spatial resolution of MRI with the remarkably high sensitivity of PET, they also generate a significant contrast enhancement on the MR image, the latter of which can be made biomarker-responsive by appropriate chelate design. ${ }^{18-21}$ Importantly, such information cannot be obtained through PET/MR protocols performed by injecting a sole PET tracer. 
In order to further benefit from the synergistic combination of PET and MR imaging, a bimodal manganese tracer should ideally possess at least one of the following features: (i) specificity to a tissue/disease of interest, (ii) marked MR contrast enhancement (i.e. high $r_{1}$ ), or (iii) biomarker responsiveness (i.e. $r_{1}$ varies with the occurrence of a biological process, which can hence be monitored). Achievement of any of those three properties, respectively, requires the manganese complex (i) to be derivatized with a targeting moiety, (ii) to be coupled to a multivalent, small and rigid molecular entity ${ }^{22-25}$, or (iii) to be functionalized with a scaffold whose chemical modification through a biological event influences the CA relaxivity. ${ }^{20} \mathrm{~A}$ bifunctional manganese(II) chelator (BFMnC), i.e. a ligand bearing a functional group for further synthetic modification, is therefore needed to design such “optimized” PET/MR tracers.

Until now, reports describing tailor-made BFMnC for high stability/relaxivity CAs are rather scarce. Very recently, the Caravan group took advantage of the trans-1,2-diaminocyclohexane backbone to build the PyC3A chelator (Chart 2, A1), which forms a very stable and inert monoaquated $\mathrm{Mn}^{\mathrm{II}}$ complex, as well as the corresponding BFMnC, $t$ Bu-PyC3A-NHS (Chart 2, A2). ${ }^{26}$ After coupling four molecules of $\mathbf{A} 2$ to a fibrin-binding peptide and $\mathrm{Mn}^{\mathrm{II}}$ chelation, the obtained high relaxivity $\mathrm{MR}$ CA permitted efficient thrombus detection in a rat model combined with rapid elimination from the body without dechelation. Previously, the same research group synthesized a backbone-substituted EDTA precursor (Chart 2, B) and reported its 6-fold attachment to a central cyclotriphosphazene core. ${ }^{22}$ The corresponding hexameric $\mathrm{Mn}^{\mathrm{II}}$ dendrimer exhibited high relaxivity and was proposed as a non-Gd ${ }^{\text {III }}$ CA ideally suited for CKD patients given its mixed renal and hepatobiliary clearance. Additionally, Wu et al. published a rigidified open-chain BFMnC (Chart 2, C) which was coupled to amphiphilic dextran micelles by CuAAC. ${ }^{27}$ After $\mathrm{Mn}^{\mathrm{II}}$ loading, the increased $T_{1}$-relaxivity of the obtained nanomicelles allowed for good MR signal enhancement of the vasculature. Although the kinetic inertness of the $\mathrm{Mn}^{\mathrm{II}}$ complexes of $\mathbf{B}$ and $\mathbf{C}$ has not been determined, data available in the literature indicate that both chelates are most certainly not as kinetically inert as the ones formed with more rigid hexadentate chelators like CDTA and PyC3A $\left(t_{1 / 2}[\mathrm{Mn}(\mathrm{EDTA})]^{2-} \approx 5 \mathrm{~min}\right.$., $\mathrm{pH} 7.4,25$ $\left.{ }^{\circ} \mathrm{C}\right) .{ }^{22}$ Based on the favorable properties of $[\mathrm{Mn}(\mathrm{CDTA})]^{2-}$ as well as on prior experience with this ligand, ${ }^{17}$ the synthesis of a CDTA-based BFMnC was undertaken. 

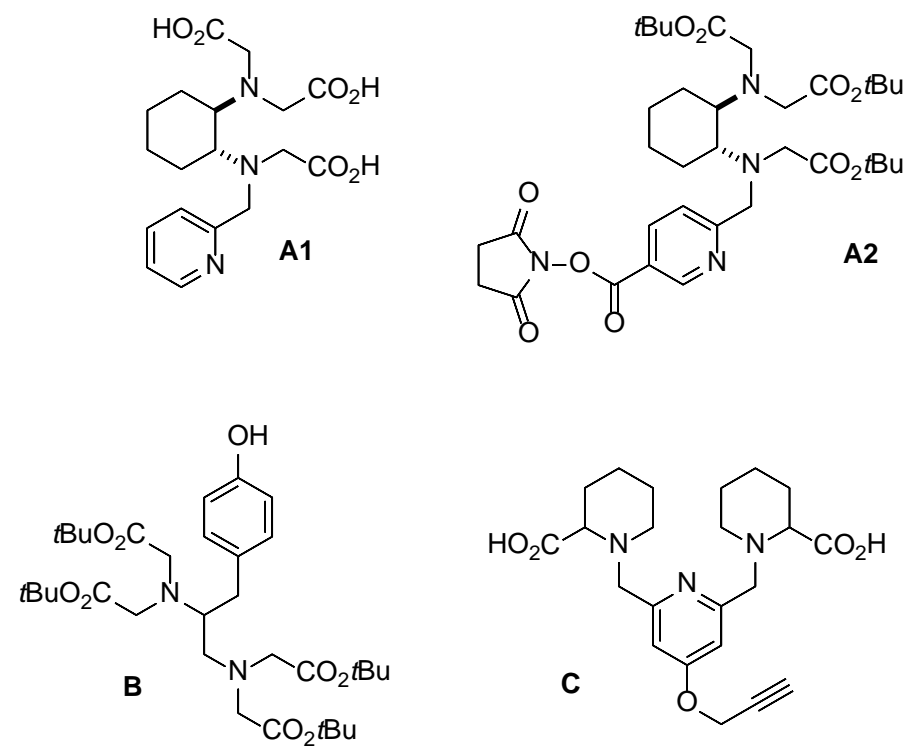

Chart 2. Recently published BFMnCs (see text for references). It should be noted that the chelating motif of A2 and B was deprotected after coupling to a peptide/small multifunctional entity.

Herein, the rational design and synthesis of a CDTA-based BFMnC for stable $\mathrm{Mn}^{\mathrm{II}}$ complexation is described. A chemical handle for synthetic modification was implemented on the cyclohexyl ring of the chelator. The impact of this substituent on the characteristics of the corresponding $\mathrm{Mn}^{\mathrm{II}}$ complex was assessed in solution through thermodynamic, kinetic as well as NMR relaxometric studies performed on [Mn(4-HET-CDTA)] $]^{2-}$ as "model complex". The obtained results were compared to those reported for the parent $[\mathrm{Mn}(\mathrm{CDTA})]^{2-}$ and other relevant $\mathrm{Mn}^{\mathrm{II}}$ chelates.

\section{Results and discussion}

\section{Design and synthesis of the bifunctional Mn ${ }^{I I}$ chelator (BFMnC)}

At first glance, inserting the functional group for further derivatization on one of the pendant acetate substituents of CDTA appears as the shortest path to a bifunctional chelator. ${ }^{26}$ However, a chemical attachment point located that close to the future $\mathrm{Mn}^{\mathrm{II}}$ coordination cage may potentially alter the stability and/or the relaxivity of the final complex. In order to reduce this risk, it appeared safer to install the chemical handle on the cyclohexyl ring: for this reason, 3-cyclohexene-1-methanol was chosen as starting compound in our synthetic route.

The cyclohexene moiety of this inexpensive building block allows forming the trans-1,2diaminocyclohexane backbone, while its hydroxyl group can be converted into a highly reactive functional group for chemoselective coupling reactions. Among such transformations, the $\mathrm{Cu}^{\mathrm{I}-}$ catalyzed azide-alkyne 1,3-dipolar cycloaddition (CuAAC) ${ }^{28}$ is a prominent member of the "click" reaction family ${ }^{29}$ which has shown widespread use in the synthesis of targeted or other optimized imaging probes. ${ }^{23}$, 30-33 $\mathrm{CuAAC}$ is of particular interest as the hydroxyl group of 3-cyclohexene-1- 
methanol enables an uncomplicated introduction of the required alkyne or azide functionalities, both of which are very inert to most chemical reagents and functional groups.

The here proposed target BFMnCs, i.e. CuAAC-reactive CDTA-based compounds $\mathbf{6 a}$ and $\mathbf{6 b}$, are depicted in Scheme 1A. Strictly speaking, the latter are not bifunctional $\mathrm{Mn}^{\mathrm{II}}$ chelators per se, as $t \mathrm{Bu}$ esters still have to be cleaved to unmask the CDTA chelating unit. However, deprotection should not be carried out before CuAAC coupling since CDTA forms very stable $\mathrm{Cu}^{\mathrm{II}}$ complexes (approx. 4-5 orders of magnitude more stable than $[\mathrm{Mn}(\mathrm{CDTA})]^{2-}$ ) that might drastically complicate "click"catalyst removal. As the presence of copper likely precludes efficient radiolabeling of the final "click"conjugate, the selected approach towards bimodal PET/MR probes is based on the following reaction sequence: (i) CuAAC-coupling of protected derivative $\mathbf{6 a}$ or $\mathbf{6 b}$ to a molecule of interest, (ii) removing copper from the obtained conjugate, (iii) deprotecting the acetate pendant arms with TFA, (iv) final step radiolabeling with c.a. ${ }^{52 \mathrm{~g}} \mathrm{Mn}$ (Scheme 1B). It should be mentioned that due to the presence of excess copper and given the conditions required for $t \mathrm{Bu}$ ester deprotection, the proposed approach is applicable for the coupling of relatively stable targeting vectors such as peptides rather than antibodies or other sensitive biomolecules.
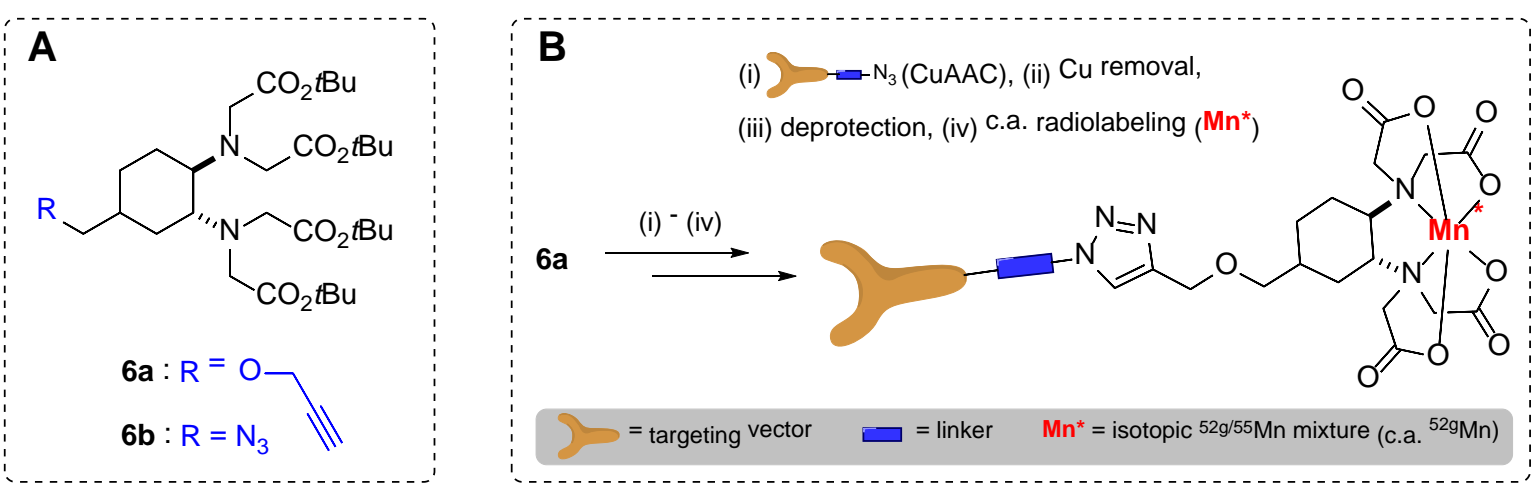

Scheme 1. (A) Structure of the desired BFMnCs 6a (or 4-P-CDTA $\left.(t \mathrm{Bu})_{4}\right)$ and $\mathbf{6 b}$ (or 4-A-CDTA $\left.(t \mathrm{Bu})_{4}\right)$. (B) Synthesis strategy for a targeted bimodal PET/MR probe starting from $\mathbf{6 a}$.

The synthesis of the BFMnCs started with the protection of the hydroxyl group of 3-cyclohexene1-methanol as tert-butyldiphenylsilyl ether (Scheme 2). The second step already appeared as the most crucial transformation in the synthesis route as it is required to provide the trans-1,2diaminocyclohexane backbone needed to promote the kinetic inertness of the corresponding manganese chelate. ${ }^{11,26}$ Initial measurements performed in our laboratory showed that the dissociation half-life $\left(t_{1 / 2}, \mathrm{pH} 7.4,25^{\circ} \mathrm{C}\right)$ is approx. 25-times higher for [Mn(trans-CDTA) $]^{2-}$ than for $[\mathrm{Mn}($ cisCDTA) $]^{2-34}$, further demonstrating that a suitable BFMnC has to be built on the trans-1,2diaminocyclohexane scaffold. The precursor of choice, trans-1,2-diazidocyclohexane 2 , was obtained by 1,2-diazidonation of the alkene in the presence of $\mathrm{NaN}_{3}$ and $\mathrm{Mn}(\mathrm{OAc})_{3} \cdot 2 \mathrm{H}_{2} \mathrm{O} .{ }^{35}$ According to the literature, this reaction usually yields a mixture of cis- and trans-1,2-diazides when performed on 
cyclohexene derivatives, with the trans-isomer being formed predominantly. ${ }^{35-38}$ However, Galanski et $a l$. as well as Habala et al. applied the same transformation to 4-methylcyclohexene and reported the stereospecific formation of the corresponding trans-1,2-diazide. ${ }^{39,}{ }^{40}$ In accordance with the latter work, 2 was obtained stereospecifically as the trans-1,2-diazide, existing as two isomers which differ by the orientation of the protected hydroxymethyl substituent (axial/equatorial $=90: 10$ based on ${ }^{1} \mathrm{H}$ NMR; in both isomers, the two azide substituents are equatorial - see ESI for NMR spectra and a detailed discussion). To avoid complex ${ }^{1} \mathrm{H}$ and ${ }^{13} \mathrm{C}$ NMR spectra and tedious peak assignment in the upcoming synthesis steps, it was decided to solely isolate the predominantly formed 4-axial isomer. Removal of several by-products as well as the minor isomer (4-equatorial) was achieved by means of repeated column chromatography (petroleum ether/diethyl ether 99:1), yielding $62 \%$ of isolated 4axial isomer. The quantitative reduction to trans-1,2-diamine 3 via hydrogenation over Pd/C catalyst was followed by full alkylation of the two primary amines with tert-butyl bromoacetate, producing tetraester $\mathbf{4}$ in $65 \%$ yield. In the next step, the 4-hydroxymethyl derivative $\mathbf{5}$ was obtained after deprotection using tetrabutylammonium fluoride (TBAF; 85\% yield).

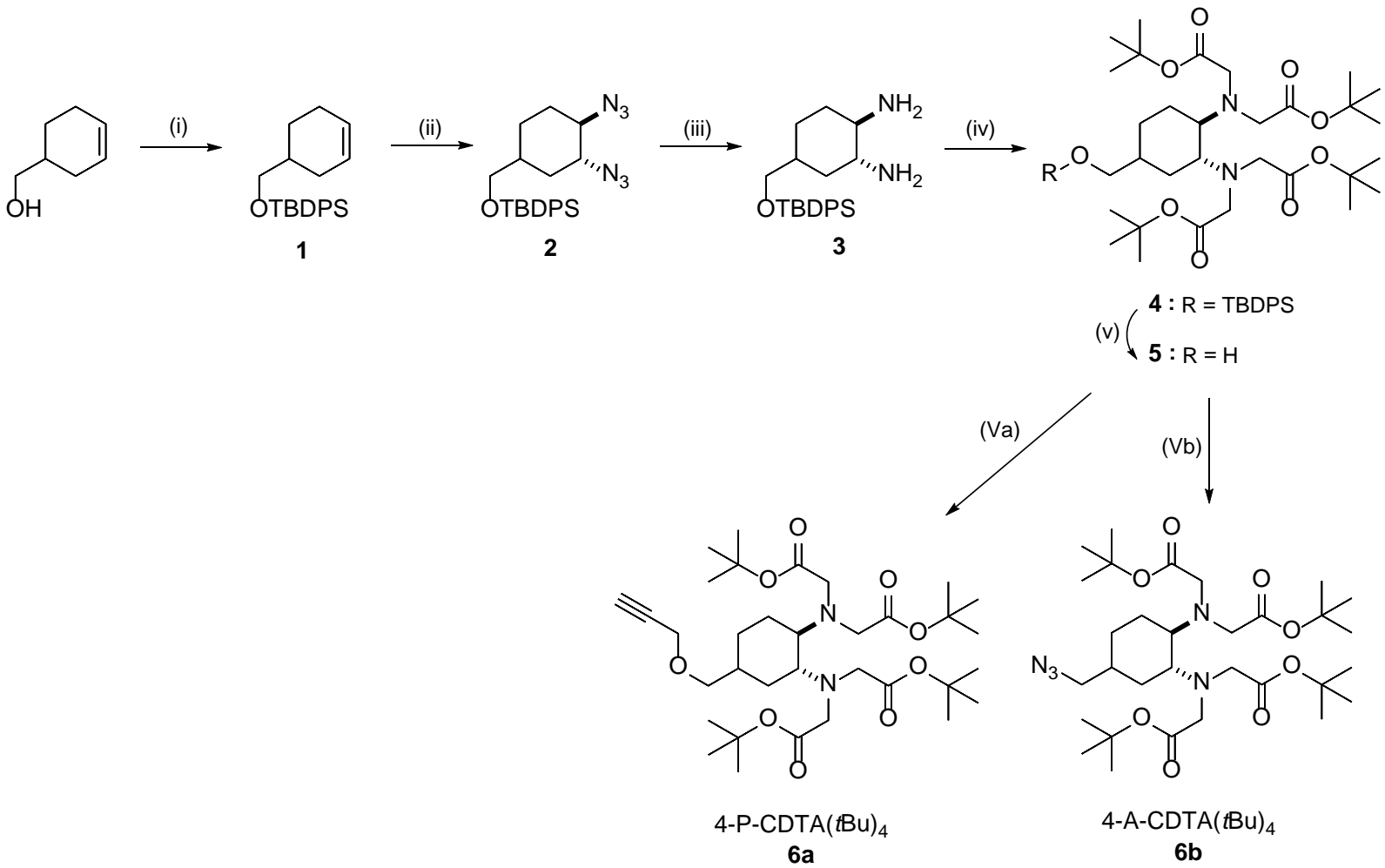

Scheme 2. Synthetic scheme for the preparation of 4-P-CDTA $(t B u)_{4}(\mathbf{6 a})$ and 4-A-CDTA $(t B u)_{4}(\mathbf{6 b})$. Reagents and conditions: (i) TBDPSCl, imidazole, $\mathrm{CH}_{2} \mathrm{Cl}_{2}$, RT, 97 \%. (ii) $\mathrm{NaN}_{3}, \mathrm{Mn}(\mathrm{OAc})_{3} .2 \mathrm{H}_{2} \mathrm{O}, \mathrm{TFA}, \mathrm{CH}_{3} \mathrm{CN} / \mathrm{CH}_{2} \mathrm{Cl}_{2}$, $-20^{\circ} \mathrm{C}, 62 \%$. (iii) $\mathrm{H}_{2}, \mathrm{Pd} / \mathrm{C}, \mathrm{EtOAc} / \mathrm{MeOH}, \mathrm{RT}$, quantitative. (iv) tert-butyl bromoacetate, $\mathrm{K}_{2} \mathrm{CO}_{3}, \mathrm{DMF}, 50^{\circ} \mathrm{C}$, $65 \%$. (v) TBAF, THF, $0^{\circ} \mathrm{C} \rightarrow \mathrm{RT}, 85 \%$. (a) propargyl bromide, $\mathrm{CsOH} . \mathrm{H}_{2} \mathrm{O}, \mathrm{CH}_{2} \mathrm{Cl}_{2}, 0^{\circ} \mathrm{C} \rightarrow \mathrm{RT}, 75 \%$. (b) 1 . $\mathrm{MsCl}, \mathrm{Et}_{3} \mathrm{~N}, \mathrm{CH}_{2} \mathrm{Cl}_{2}, 0^{\circ} \mathrm{C} \rightarrow \mathrm{RT} ; 2$. $\mathrm{NaN}_{3}, \mathrm{DMF}, 75^{\circ} \mathrm{C}, 70 \%$ (2 steps). 
Once the $t \mathrm{Bu}$ ester-protected CDTA backbone was built, derivatization of the hydroxymethyl substituent of $\mathbf{5}$ with the alkyne/azide moiety needed for CuAAC coupling reactions was performed. The triple bond was inserted via $O$-alkylation using propargyl bromide, cesium hydroxide monohydrate and tetrabutylammonium iodide (TBAI) in dichloromethane. This method proved to be extremely fast and efficient for alkylating two hydroxymethyl groups on a DOTA derivative (90 min reaction time, $90 \%$ yield). ${ }^{30}$ Carried out on 5 , however, the reaction appeared significantly more sluggish, small amounts of starting material still being detected by TLC after $18 \mathrm{~h}$ stirring with 8 equivalents bromide and 4 equivalents base. When the reaction was performed in the presence of activated $4 \AA$ powdered molecular sieve but without TBAI, ${ }^{41}$ the alcohol underwent almost full conversion within 18 hours at RT and $\mathbf{6 a}$ was obtained in 75\% yield after column chromatography.

The azido-BFMnC $\mathbf{6 b}$ was synthesized by conversion of $\mathbf{5}$ to the corresponding mesylate followed by substitution of the latter with sodium azide in DMF. After removal of a low amount of elimination product which was formed during the first step, 4-A-CDTA $(t \mathrm{Bu})_{4}$ was isolated in $70 \%$ yield (over 2 steps). To the best of our knowledge, $\mathbf{6 a}$ and $\mathbf{6 b}$ are the first CDTA-based backbone-functionalized BFMnCs published so far. The only other example of a bifunctional chelator specifically designed to yield $\mathrm{Mn}^{\mathrm{II}}$-based CAs with elevated stability, inertness and relaxivity is $t$ Bu-PyC3A-NHS already mentioned in the introduction (structure $\mathbf{A} 2$ in Chart 2).

Rather than evaluating the $\mathrm{Mn}^{\mathrm{II}}$ chelates of deprotected $\mathbf{6 a} / \mathbf{6 b}$ in terms of equilibrium, kinetic and relaxometric properties, the "model chelator" 4-HET-CDTA was synthesized (8a, Scheme 3; the 4substituent is axial whereas the iminodiacetate groups are diequatorial - see ESI for NMR spectra and a detailed discussion). The latter was obtained by "clicking” alkyne 6a with 2-azidoethanol in the presence of copper(I) iodide ${ }^{30}$ followed by $t$ Bu ester cleavage of intermediate 7a using TFA. 4-HETCDTA bears a 1,2,3-triazole moiety on its cyclohexyl ring substituent, as will be the case for the “click"-conjugates intended to be radiolabeled with ${ }^{52 \mathrm{~g} / 55} \mathrm{Mn}^{\mathrm{II}}$ (Scheme 1B). Therefore, the parameters obtained for [Mn(4-HET-CDTA)] $]^{2-}$ should be much more relevant than data generated with the chelates of deprotected $\mathbf{6 a} / \mathbf{6 b}$. While the hydroxyethyl side-chain of 4-HET-CDTA is expected to havelittle to no effect on the thermodynamic properties of the final complex, the potential impact of the coordinating $N$-substituted 1,2,3-triazole moiety on the structural, dynamic and relaxometric properties of the chelate is of particular interest. ${ }^{42,} 43$ A "model chelator" obtained by "clicking” and deprotecting $6 \mathrm{~b}$ would have a triazole moiety that is

In that context, as a "model chelator" derived from $6 \mathrm{~b}$ would have a shorter and less flexible linker between the cyclohexane ring and the triazole than 


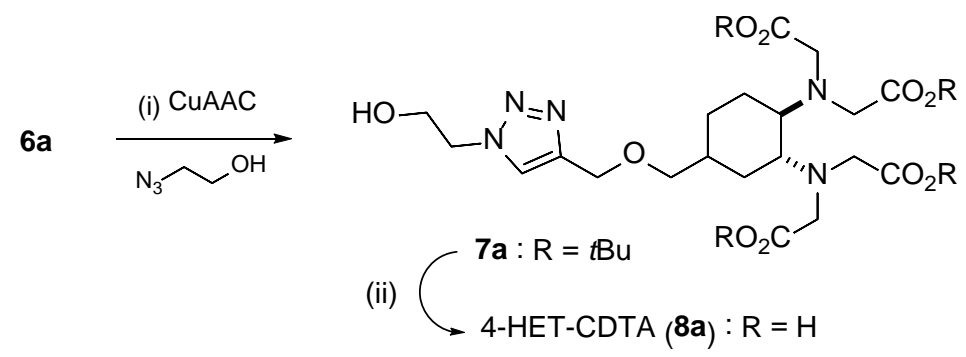

Scheme 3. Synthesis of model compound 4-HET-CDTA (8a) by "click"-coupling between 6a and 2azidoethanol followed by deprotection of the acetate pendant arms. Reagents and conditions: (i) 2-azidoethanol, CuI, DIPEA, 2,6-lutidine, $\mathrm{CH}_{2} \mathrm{Cl}_{2}$, RT, 70\%; (ii) TFA/ $\mathrm{CH}_{2} \mathrm{Cl}_{2}$ 1:1, RT, 76\%.

\section{Solution equilibrium studies}

\section{Determination of protonation constants}

As a first step, the protonation constants of the 4-HET-CDTA chelator were measured by $\mathrm{pH}$ potentiometric titration in $0.15 \mathrm{M} \mathrm{NaCl}$, which is considered to better mimic the conditions present in biological fluids than other electrolyte solutions do. The ligand protonation constants are defined as shown in eq. 1 :

$$
K_{\mathrm{i}}^{\mathrm{H}}=\frac{\left[\mathrm{H}_{\mathrm{i}} \mathrm{L}\right]}{\left[\mathrm{H}_{\mathrm{i}-1} \mathrm{~L}\right]\left[\mathrm{H}^{+}\right]}
$$

where $\mathrm{i}=1,2$ and $\mathrm{L}$ denotes the deprotonated ligand.

The protonation constants obtained for 4-HET-CDTA along with the data corresponding to the parent CDTA are listed and compared in Table 1. As can be seen from those values, the presence of the 1,2,3-triazole-bearing substituent on the cyclohexane ring of 4-HET-CDTA results in a minor decrease of the basicity of the amine nitrogen atoms $\left(\Delta \log K_{1}{ }^{H}=0.5, \Delta \log K_{2}{ }^{H}=0.2\right)$, most likely due to the slight electron-withdrawing effect of the triazole unit. This makes the 4-HET-CDTA ligand altogether marginally less basic than non-functionalized CDTA $\left(\Delta \Sigma \log K_{\mathrm{i}}^{\mathrm{H}}=0.8\right)$. For comparison purposes, Table 1 also lists the data reported for EDTA and 1,4-DO2A (Chart 1), a macrocyclic chelator whose $\mathrm{Mn}^{\mathrm{II}}$ complex was shown to combine a reasonably high relaxivity with good thermodynamic stability and kinetic inertness. ${ }^{10,} 12$ The 1,4-DO2A ligand is significantly more basic than 4-HET-CDTA, CDTA and EDTA $\left(\Delta \Sigma \log K_{\mathrm{i}}^{\mathrm{H}}=4.4,3.6\right.$ and 5.3 respectively).

Table 1. Protonation constants of 4-HET-CDTA, CDTA, EDTA and 1,4-DO2A ( $I=0.15 \mathrm{M} \mathrm{NaCl}, T$ $\left.=25^{\circ} \mathrm{C}\right)$. 


\begin{tabular}{|c|c|c|c|c|}
\hline & 4-HET-CDTA ${ }^{[\mathrm{a}]}$ & $\mathrm{CDTA}^{[\mathrm{b}]}$ & EDTA $^{[\mathrm{b}]}$ & $1,4-\mathrm{DO} 2 \mathrm{~A}^{[\mathrm{cc}]}$ \\
\hline $\log K_{1}{ }^{\mathrm{H}}$ & $8.99(2)$ & 9.36 & 9.17 & 11.44 \\
\hline $\log K_{2}{ }^{\mathrm{H}}$ & $5.75(3)$ & 5.95 & 5.99 & 9.51 \\
\hline $\log K_{3}{ }^{\mathrm{H}}$ & $3.67(3)$ & 3.62 & 2.73 & 4.14 \\
\hline $\log K_{4}{ }^{\mathrm{H}}$ & $2.47(4)$ & 2.57 & 2.01 & 1.55 \\
\hline $\log K_{5}{ }^{\mathrm{H}}$ & $1.37(4)$ & 1.49 & 1.38 & - \\
\hline$\sum \log K_{\mathrm{i}}^{\mathrm{H}}$ & 22.25 & 22.99 & 21.28 & 26.64 \\
\hline
\end{tabular}

[a] The data in brackets are the standard deviations; [b] ref. ${ }^{11}$; [c] ref. ${ }^{12}$

Stability of the complexes formed with $M n^{I I}$ and other essential metal ions

In order to obtain thermodynamic insights of the formation of 4-HET-CDTA complexes with $\mathrm{Mn}^{\mathrm{II}}$ as well as the essential metals $\mathrm{Cu}^{\mathrm{II}}, \mathrm{Mg}^{\mathrm{II}}, \mathrm{Ca}^{\mathrm{II}}$ and $\mathrm{Zn}^{\mathrm{II}}$, their stability and protonation constants $\left(K_{\mathrm{ML}}\right.$ and $K_{\mathrm{MHiL}}$, respectively) were determined by $\mathrm{pH}$-potentiometric titration, excepted for $\mathrm{Cu}^{\mathrm{II}}$. For the chelate formed with this ion, pH-potentiometry had to be complemented with UV-Vis spectrophotometric measurements. Although the titration data were fitted by considering the formation of mononuclear complexes (ML), the existence of protonated species at lower $\mathrm{pH}$ values had to be taken into account for $\mathrm{Ca}^{\mathrm{II}}$ and $\mathrm{Mn}^{\mathrm{II}}$ (MHL complex) as well as for $\mathrm{Zn}^{\mathrm{II}}$ and $\mathrm{Cu}^{\mathrm{II}}$ ( $\mathrm{MH}_{2} \mathrm{~L}$ complex). The formation of ternary hydroxydo complexes $(\mathrm{ML}(\mathrm{OH}))$, which usually appear at higher $\mathrm{pH}$, was not confirmed for any of the studied metal ions up to $\mathrm{pH}=11.80$. The thermodynamic stability and protonation constants of the different metal chelates are expressed by eq. 2 and 3, respectively.

$$
\begin{array}{r}
K_{\mathrm{ML}}=\frac{[\mathrm{ML}]}{[\mathrm{M}][\mathrm{L}]} \\
K_{\mathrm{MH}_{\mathrm{i}} \mathrm{L}}=\frac{\left[\mathrm{MH}_{\mathrm{i}} \mathrm{L}\right]}{\left[\mathrm{MH}_{\mathrm{i}-1} \mathrm{~L}\right]\left[\mathrm{H}^{+}\right]} \quad \text { where } \mathrm{i}=1,2
\end{array}
$$

For the $\mathrm{Cu}^{\mathrm{II}}$ system, it was not possible to obtain an acceptable fit of the experimental $\mathrm{pH}$ potentiometric data (volume of $\mathrm{NaOH}$ added vs. $\mathrm{pH}$ ) since the absence of free $\mathrm{Cu}^{\mathrm{II}}$ was observed even at the most acidic titration point $(\mathrm{pH}=1.73)$. Therefore, the formation of this complex had to be studied under fairly acidic conditions using a batch method (samples prepared over the $\left[\mathrm{H}^{+}\right]$range of $\left.0.02-1.0 \mathrm{M} ;\left[\mathrm{H}^{+}\right]+\left[\mathrm{Na}^{+}\right]=1.0 \mathrm{M}\right)$. The corresponding absorption spectra recorded for the $\mathrm{Cu}^{\mathrm{II}}: 4-$ HET-CDTA : $\mathrm{H}^{+}$system between $400-875 \mathrm{~nm}$ are shown in Figure 1. These data were fitted simultaneously with the ones obtained by $\mathrm{pH}$-potentiometry (titration at 1:1 and 2:1 metal-to-ligand 
ratio in the $\mathrm{pH}$ range $1.73-11.80$ and $1.70-5.00$, respectively). The thermodynamic stability constants obtained for the different 4-HET-CDTA complexes are presented in Table 2 and compared with those of their EDTA, CDTA and 1,4-DO2A analogues. The values highlight that 4-HET-CDTA forms chelates of slightly lower stabilitiy than CDTA $\left(\Delta \log K_{\mathrm{ML}}=0.4-0.7\right)$ which is the consequence of the lower ligand basicity. In the case of the $\mathrm{Mn}^{\mathrm{II}}$ complexes, the calculated $\mathrm{pMn}$ value (which can be considered as a conditional stability constant; $\mathrm{pMn}=-\log \left[\mathrm{Mn}^{\mathrm{II}}\right]_{\text {free }}$ at $25^{\circ} \mathrm{C}, \mathrm{pH}=7.4$ and $\mathrm{c}_{\mathrm{MnII}}=$ $\left.\mathrm{C}_{\mathrm{L}}=1 \times 10^{-5} \mathrm{M}\right)^{44}$ is almost identical for both complexes ( $\mathrm{pMn}=8.62 \mathrm{vs.} 8.68$, respectively).

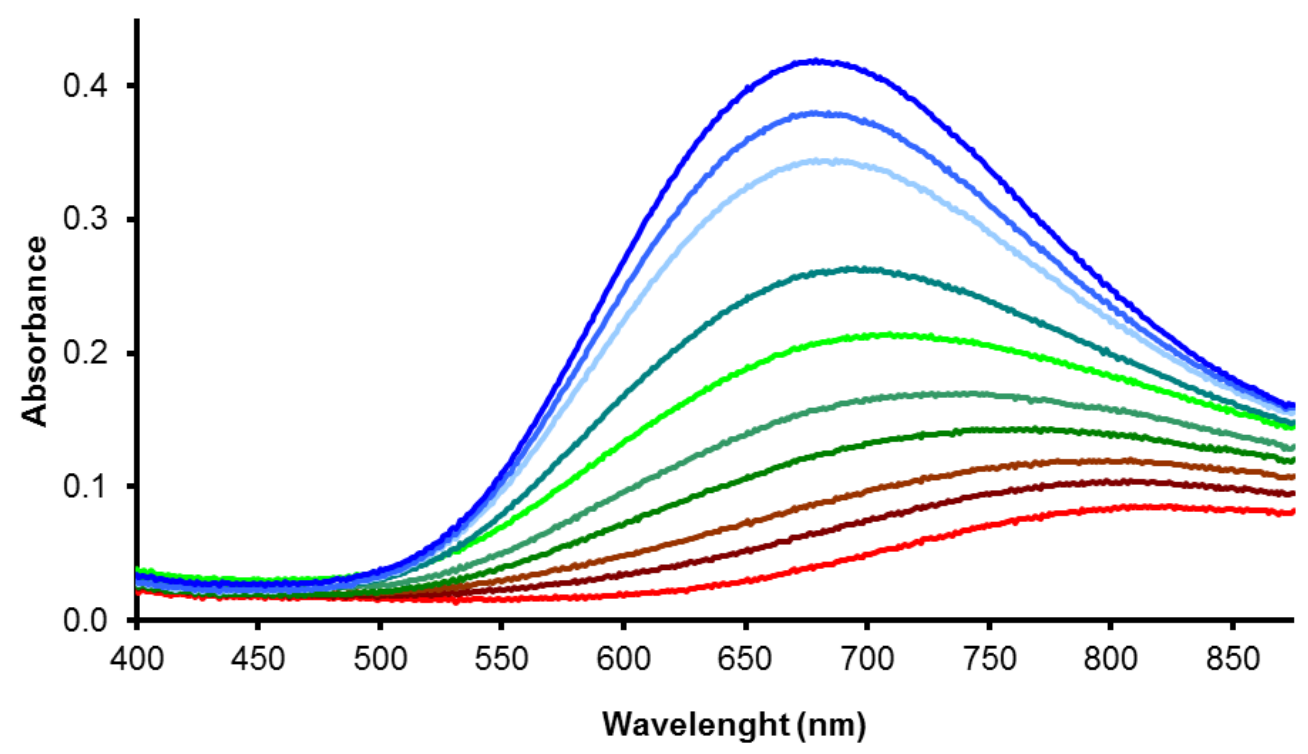

Figure 1. Absorption spectra of the $[\mathrm{Cu}(4-\mathrm{HET}-\mathrm{CDTA})]^{2-}$ system as a function of $\mathrm{c}_{\mathrm{H}+}$. Conditions: $\mathrm{c}_{\mathrm{L}}=3.475$ $\mathrm{mM}$, $\mathrm{C}_{\mathrm{CuII}}=3.422 \mathrm{mM}, 2{ }^{\circ} \mathrm{C}, 1.0 \mathrm{M}\left(\mathrm{Na}^{+}+\mathrm{H}^{+}\right) \mathrm{Cl}^{-}, \mathrm{C}_{\mathrm{H}^{+}}$in the samples was 18.8; 34.1; 49.7; 99.6; 149; 200; 250; 349; 450 and $999 \mathrm{mM}$ (from top to bottom).

As expected, the highest stability constant was measured for the $\mathrm{Cu}^{\mathrm{II}}$ complex, the latter ion also leading to the largest difference in thermodynamic stability between 4-HET-CDTA and CDTA complexes $\left(\Delta \log K_{\mathrm{CuL}}=1.5\right)$. This may be attributed to the lower ligand basicity as the stability constant of $[\mathrm{Cu}(4-\mathrm{HET}-\mathrm{CDTA})]^{2-}$ had to be determined in $1.0 \mathrm{M}$ instead of $0.15 \mathrm{M} \mathrm{NaCl}\left(\log K_{1}{ }^{\mathrm{H}}=\right.$ 8.78(2), $\log K_{2}{ }^{\mathrm{H}}=5.68(3), \log K_{3}{ }^{\mathrm{H}}=3.59(3), \log K_{4}{ }^{\mathrm{H}}=2.59(3)$ and $\log K_{5}{ }^{\mathrm{H}} 1.24(3)$ making $\Sigma \log K_{\mathrm{i}}^{\mathrm{H}}=$ 21.88 in $1.0 \mathrm{M} \mathrm{NaCl}$ and $25^{\circ} \mathrm{C}$ ). In the presence of $1.0 \mathrm{M} \mathrm{Na}^{\mathrm{I}}$ ions, the ligand forms a weak sodium complex in alkaline solution which leads to a reduced basicity (a similar decrease was reported for the protonation constants of several polyaminocarboxylate ligands such as EDTA, CDTA and DOTA). ${ }^{45-47}$

Focusing solely on the data for the $\mathrm{Mn}^{\mathrm{II}}$ complexes, one observes that the thermodynamic stability decreases in the order 1,4-DO2A > CDTA $>$ 4-HET-CDTA > EDTA, which is in perfect agreement with the $\Sigma \log K_{\mathrm{i}}^{\mathrm{H}}$ values discussed in the previous section. Interestingly, the pMn value for [Mn(1,4DO2A)] is significantly lower than those calculated for the $\mathrm{Mn}^{\mathrm{II}}$ complexes of EDTA, 4-HET-CDTA 
and CDTA. This can be explained in terms of differences between the ligand protonation constants (e.g. the conditional stability of the given complex is the lowest among these chelates): while for 1,4DO2A the first two protonation constants $\left(\log K_{1}{ }^{\mathrm{H}}\right.$ and $\log K_{2}{ }^{\mathrm{H}}$ ) are greater than $\mathrm{pH} 7.4$, only $\log {K_{1}}^{\mathrm{H}}$ is $>7.4$ for EDTA, CDTA and 4-HET-CDTA. Consecutively, the proton competition at physiological $\mathrm{pH}$ is considerably greater for the 1,4-DO2A ligand than for the CDTA's, resulting in a lower conditional stability constant as well as a lower $\mathrm{pMn}$ value for its $\mathrm{Mn}^{\mathrm{II}}$ complex.

Table 2. Stability constants ( $\log K_{\mathrm{ML}}$ ), protonation constants (log $\left.K_{\mathrm{MHiL}}\right)$ and pMn values for metal complexes formed with 4-HET-CDTA, CDTA, EDTA and 1,4-DO2A $\left(I=0.15 \mathrm{M} \mathrm{NaCl}, T=25^{\circ} \mathrm{C}\right)$.

\begin{tabular}{|c|c|c|c|c|c|}
\hline & & 4-HET-CDTA ${ }^{[\mathrm{a}]}$ & $\mathrm{CDTA}^{[\mathrm{b}]}$ & EDTA $^{[b]}$ & $1,4-\mathrm{DO} 2 \mathrm{~A}^{[\mathrm{c}]}$ \\
\hline \multirow{2}{*}{$\sum_{\sum}^{000}$} & $\log K_{\mathrm{ML}}$ & 8.69(1) & 9.14 & 7.61 & - \\
\hline & $\log K_{\mathrm{MHL}}$ & - & 3.53 & - & - \\
\hline \multirow{2}{*}{$\pi$} & $\log K_{\mathrm{ML}}$ & $9.86(1)$ & 10.23 & 9.53 & 8.62 \\
\hline & $\log K_{\mathrm{MHL}}$ & $3.50(2)$ & 3.58 & 2.92 & - \\
\hline \multirow{4}{*}{ 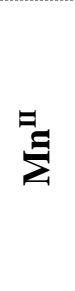 } & $\log K_{\mathrm{MnL}}$ & $13.80(3)$ & $14.32^{[\mathrm{e}]}$ & $12.46^{[\mathrm{e}]}$ & $15.68^{[f]}$ \\
\hline & $\log K_{\mathrm{MnHL}}$ & $2.56(5)$ & $2.90^{[\mathrm{e}]}$ & $2.95^{[\mathrm{e}]}$ & 4.15 \\
\hline & $\log K_{\mathrm{MnH} 2 \mathrm{~L}}$ & - & $1.89^{[\mathrm{e}]}$ & $-^{[\mathrm{e}]}$ & - \\
\hline & $\mathrm{pMn}$ & $8.62^{[\mathrm{d}]}$ & $8.68^{[\mathrm{d}]}$ & $7.83^{[\mathrm{d}]}$ & $7.27^{[\mathrm{d}, \mathrm{f}]}$ \\
\hline \multirow{3}{*}{ 芯 } & $\log K_{\mathrm{ML}}$ & $16.08(1)$ & 16.75 & 15.92 & 18.03 \\
\hline & $\log K_{\mathrm{MHL}}$ & $2.58(1)$ & 2.57 & 3.23 & 3.58 \\
\hline & $\log K_{\mathrm{MH} 2 \mathrm{~L}}$ & $1.63(3)$ & 1.58 & 1.50 & 1.65 \\
\hline \multirow{3}{*}{$\exists$} & $\log K_{\mathrm{ML}}$ & $18.30(2)^{[\mathrm{g}]}$ & $19.78^{[\mathrm{g}]}$ & $19.02^{[\mathrm{g}]}$ & $24.43^{[\mathrm{g}]}$ \\
\hline & $\log K_{\mathrm{MHL}}$ & $3.02(2)$ & 2.91 & 3.15 & 2.95 \\
\hline & $\log K_{\mathrm{MH} 2 \mathrm{~L}}$ & $1.46(2)$ & 1.10 & 2.04 & - \\
\hline
\end{tabular}

[a] The data in brackets are the standard deviations; [b] data taken from the Diploma work of Veronika Józsa, 2015, University of Debrecen, Debrecen, Hungary; [c] ref..; [d] pMn values were calculated by using the approach of É. Tóth et al. $\left(25^{\circ} \mathrm{C}, \mathrm{pH}=7.4 \text { and } \mathrm{c}_{\mathrm{MnII}}=\mathrm{c}_{\mathrm{L}}=1 \times 10^{-5} \mathrm{M}\right)^{44}$; [e] ref..$^{11}$; [f] ref. ${ }^{12}$; [g] determined by UV-Vis spectrophotometry.

The $[\mathrm{Mn}(4-\mathrm{HET}-\mathrm{CDTA})]^{2-}$ complex was further studied by ${ }^{1} \mathrm{H}$-relaxometry. In order to confirm the equilibrium model, the relaxivity versus $\mathrm{pH}$ profile was compared with the species distribution curves calculated by using the stability data determined through $\mathrm{pH}$-potentiometry. Figure 2 shows that the relaxivity of $[\mathrm{Mn}(4-\mathrm{HET}-\mathrm{CDTA})]^{2-}$ is nearly constant in the $\mathrm{pH}$ range $3.8-12.20$, suggesting that neither protonation nor deprotonation occurs in the quoted $\mathrm{pH}$ range (i.e. only the [Mn(4-HET- 
CDTA) $]^{2-}$ chelate is present in solution in the given $\mathrm{pH}$ range). The significant increase in relaxivity below $\mathrm{pH}=3.8$ is due to the protonation of the $\mathrm{Mn}^{\mathrm{II}}$ complex followed by the progressive release of the $\mathrm{Mn}^{\mathrm{II}}$ ion as a result of the chelate dissociation at lower $\mathrm{pH}$. Notably, the observed relaxivity increase at acidic $\mathrm{pH}$ coincides with the chelate dissociation suggested by the species distribution curves, thereby confirming the equilibrium model.

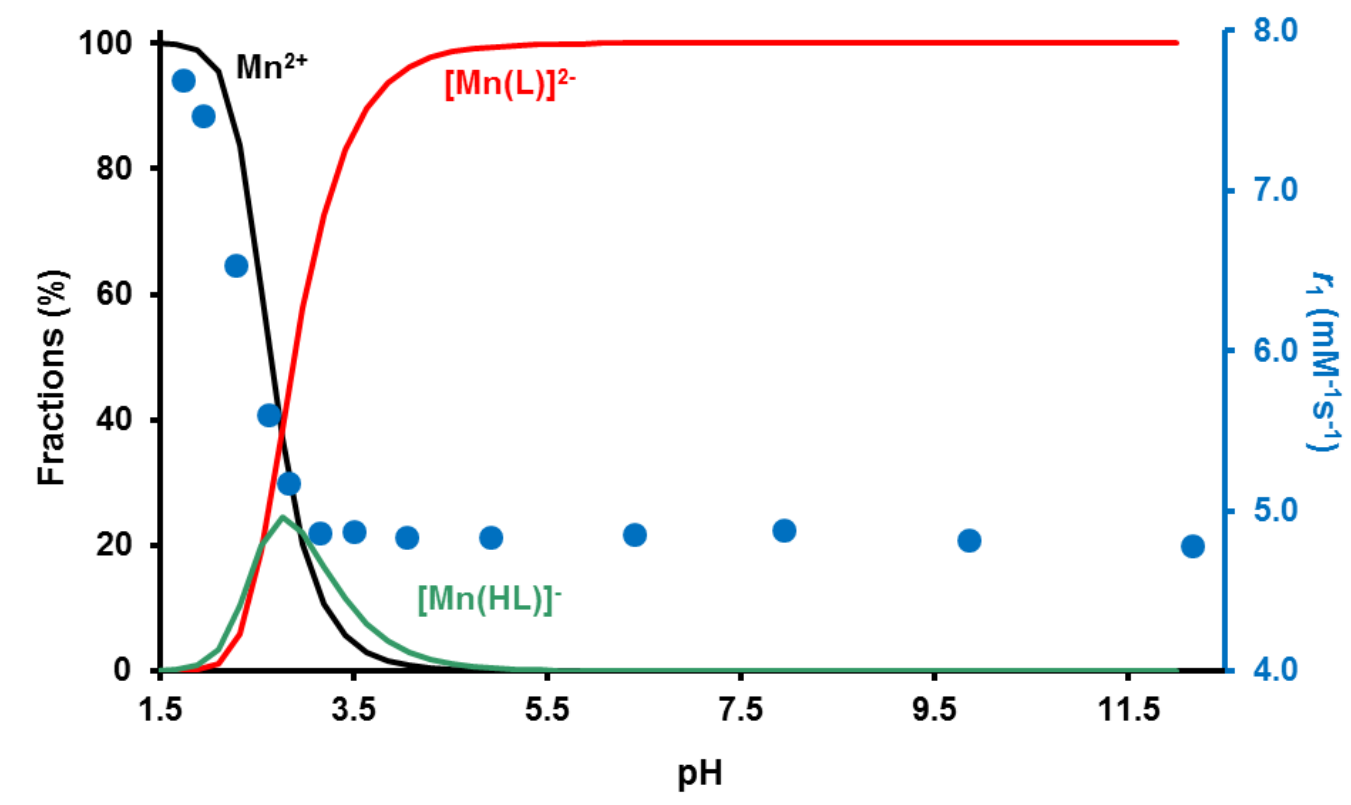

Figure 2. Relaxivity of [Mn(4-HET-CDTA) ${ }^{2-}$ as a function of pH (blue dots; $20 \mathrm{MHz}, 25{ }^{\circ} \mathrm{C}$; pH range 1.75 12.20) and the species distribution curves (solid lines) calculated by using the stability constants presented in Table 2.

The relaxivity of [Mn(4-HET-CDTA $)]^{2-}$ was determined by titrating a solution of the ligand with $\mathrm{Mn}^{\mathrm{II}}$ and found to be $r_{1}=4.56 \mathrm{mM}^{-1} \mathrm{~s}^{-1}\left(20 \mathrm{MHz}, 25^{\circ} \mathrm{C}\right.$, see Fig. S1 in ESI). This value is significantly higher than expected for a monoaquated $\mathrm{Mn}^{\mathrm{II}}$ complex of low molecular weight formed with a CDTAtype ligand $\left(r_{1}=3.65 \mathrm{mM}^{-1} \mathrm{~s}^{-1}\right.$ for $[\mathrm{Mn}(\mathrm{CDTA})]^{2-}$ under identical conditions). ${ }^{11}$ It is well-known that the relaxivity of paramagnetic metal chelates depends on many physico-chemical parameters, the most important ones being the number of coordinated water molecules $(q)$, the water exchange rate $\left(k_{\mathrm{ex}}\right)$, the electron spin relaxation times $\left(T_{1,2 \mathrm{e}}\right)$ and the rotational correlation time $\left(\tau_{\mathrm{R}}\right)$; the latter is directly related to the molecular weight. Even for ligands possessing identical donor atoms in nature and number, the corresponding $\mathrm{Mn}^{\mathrm{II}}$ complexes may have very discrepant relaxivity values (e.g. $r_{1}=1.5$, 2.1 and 3.2 $\mathrm{mM}^{-1} \mathrm{~s}^{-1}$ at $20 \mathrm{MHz}$ and $25^{\circ} \mathrm{C}$ for the $\mathrm{Mn}^{\mathrm{II}}$ complexes of hexadentate chelators 1,7-DO2A, 1,4-DO2A and EDTA, respectively). In order to identify the parameters responsible for the increased $r_{1}$ value of [Mn(4-HET-CDTA) $]^{2-}$, an in-depth evaluation of the chelate was carried out by performing NMRD (nuclear magnetic relaxation dispersion) and ${ }^{17} \mathrm{O}$ NMR experiments (vide infra). 


\section{Dissociation kinetics of the [Mn(4-HET-CDTA)] ${ }^{2-}$ complex}

In contrast to $\mathrm{Gd}^{\mathrm{III}}, \mathrm{Mn}^{\mathrm{II}}$ has an endogenous elimination pathway via the hepatobiliary system. However, exposure to large doses of the free ion has acute toxic effects as $\mathrm{Mn}^{\mathrm{II}}$ accumulates in the brain, leading to symptoms of dementia known as "manganese-induced Parkinsonism" or "manganism". ${ }^{48}$ It is nowadays recognized that kinetic inertness, which assesses the inertness of a complex towards metal release, is more important than thermodynamic stability when in vivo application of MRI CAs is considered. ${ }^{49}$ In order to evaluate the inertness of [Mn(4-HET-CDTA) $]^{2-}$ under physiological conditions, the rates of the transmetallation reactions between the complex and endogenous $\mathrm{Cu}^{\mathrm{II}}$ were studied (eq. 4) (the complex used in the studies was characterized by HPLC and MS methods, see Figure S2 and S3 in ESI). UV-Vis spectrophotometric monitoring of those reactions was performed in the presence of a high $\mathrm{Cu}^{\mathrm{II}}$ excess (10-40 fold) to ensure pseudo-first-order conditions (pH range 4.05 - 5.03).

$$
[\mathrm{Mn}(4-\mathrm{HET}-\mathrm{CDTA})]^{2-}+\mathrm{Cu}^{\mathrm{II}} \rightleftharpoons[\mathrm{Cu}(4-\mathrm{HET}-\mathrm{CDTA})]^{2-}+\mathrm{Mn}^{\mathrm{II}}
$$

Since a pseudo-first-order process is considered, the rate of the dissociation reactions can be expressed as described in eq. 5 , where $k_{\mathrm{obs}}$ is a pseudo-first-order rate constant, and $[\mathrm{MnL}]_{\mathrm{t}}$ is the total concentration of the $\mathrm{Mn}^{\mathrm{II}}$ chelate:

$$
-\frac{\mathrm{d}[\mathrm{MnL}]_{\mathrm{t}}}{\mathrm{dt}}=k_{\mathrm{obs}}[\mathrm{MnL}]_{\mathrm{t}}
$$

Figure 3 shows the calculated $k_{\text {obs }}$ rate constants as a function of the acid concentration (see Fig. S4 in ESI for the CCuII-dependence of the pseudo-first order rate constants). 


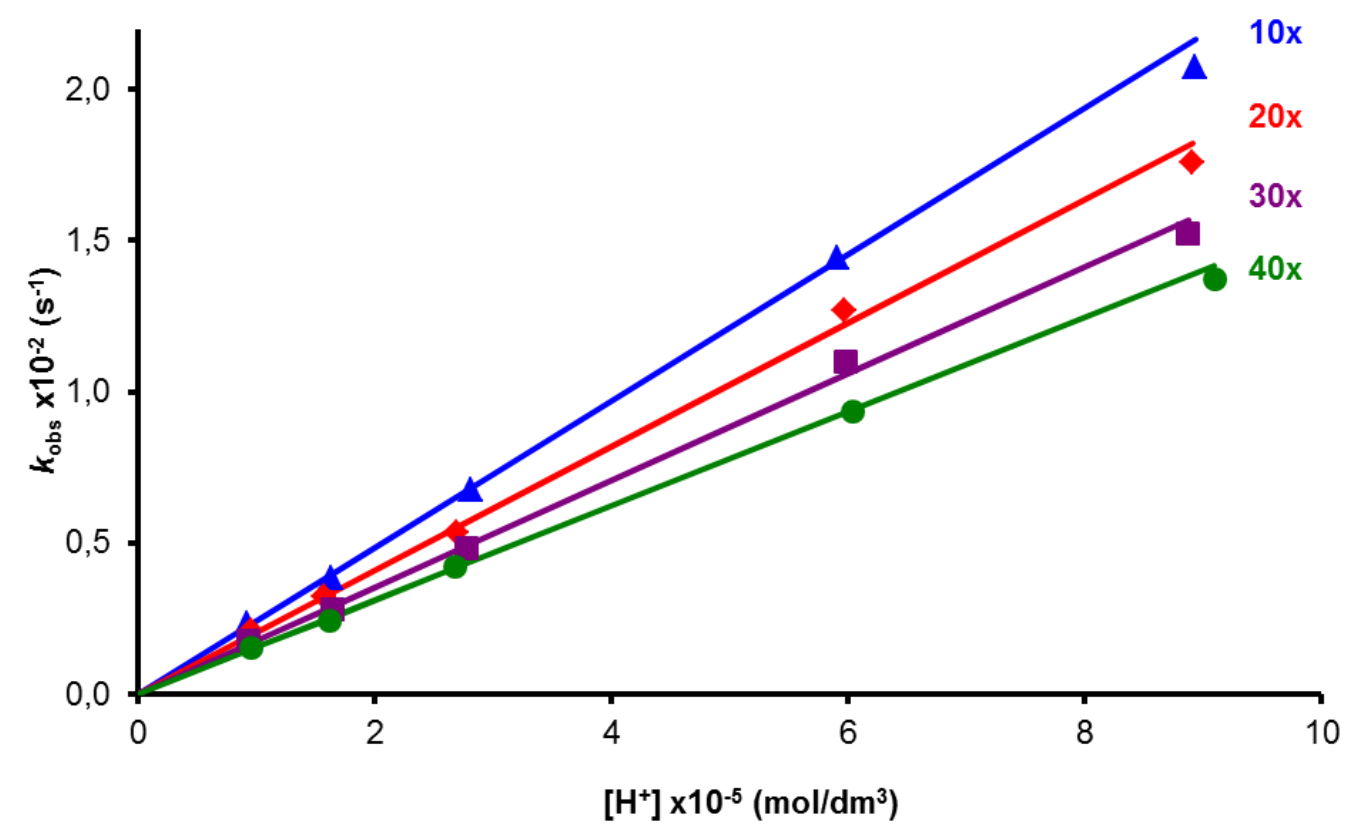

Figure 3. $\mathrm{C}_{\mathrm{H}^{+}}$dependence of the pseudo-first-order rate constants $\left(k_{\mathrm{obs}}\right)$ for the [Mn(4-HET-CDTA $\left.)\right]^{2-}$ complex $(0.4 \mathrm{mM})$ at different exchanging metal ion concentrations. c $_{\text {CuII }}=4.28 \mathrm{mM}$ (10-fold excess; blue triangles), $8.26 \mathrm{mM}$ (20-fold excess; red diamonds), $12.8 \mathrm{mM}$ (30-fold excess; purple squares) and $17.1 \mathrm{mM}$ (40fold excess; green dots). The corresponding $\mathrm{pH}$ values were the following: 5.03. 4.79, 4.56, 4.26 and 4.05 (from left to right).

As highlighted by Figure 3, the $k_{\text {obs }}$ values increase with increasing acid concentration (decreasing $\mathrm{pH})$ as well as with decreasing concentration of the exchanging ion. The relation between the $k_{\text {obs }}$ values and $\mathrm{pH}$ may be explained by a rate-determining step in which the proton-assisted dissociation of the $\mathrm{Mn}^{\mathrm{II}}$ chelate is followed by a fast complexation of the $\mathrm{Cu}^{\mathrm{II}}$ ion by the free ligand. Since the dependence of $k_{\text {obs }}$ on $\left[\mathrm{H}^{+}\right]$results in a straight line, the exchange reaction may occur via spontaneous as well as proton-assisted pathways. Additionally, the fact that $k_{\text {obs }}$ values are inversely proportional to the $\mathrm{Cu}^{\mathrm{II}}$ concentration indicates that a stable, catalytically inactive dinuclear intermediate, usually referred to as "dead-end" complex $([\mathrm{Mn}(\mathrm{L}) \mathrm{Cu}])$ is formed (its existence was confirmed by MS spectroscopy, see ESI Figure S5). ${ }^{50}$ Altogether, these experimental observations illustrate that the spontaneous dissociation, the proton-assisted dissociation and the metal ion-catalyzed dissociation have to be taken into account as possible pathways for the decomplexation of [Mn(4-HET-CDTA) $]^{2-}$ (see Fig. 4).

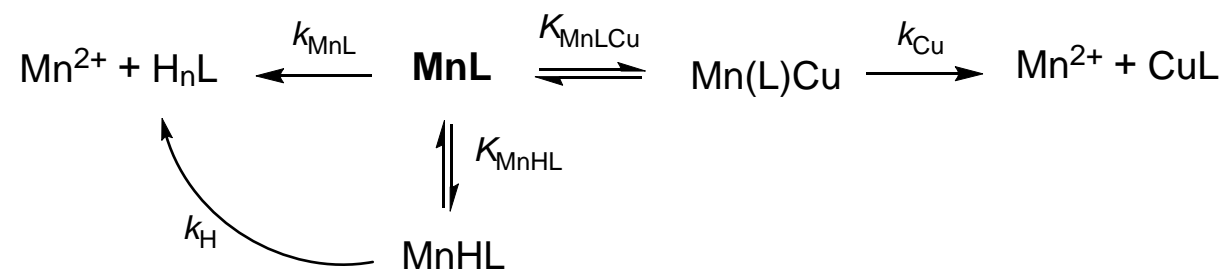


Figure 4. Possible reaction pathways for the dissociation of the [Mn(4-HET-CDTA) $]^{2-}$ complex. The different $k_{\mathrm{x}}$ and $K_{\mathrm{x}}$ constants are defined in the text.

Hence, the total $\mathrm{Mn}^{\mathrm{II}}$ chelate concentration, $[\mathrm{MnL}]_{\mathrm{t}}$, can be expressed as the sum of the concentrations of each reactive species: $[\mathrm{MnL}]_{\mathrm{t}}=[\mathrm{MnL}]+[\mathrm{MnHL}]+[\mathrm{Mn}(\mathrm{L}) \mathrm{Cu}]$. By introducing the latter into eq. 5, one obtains eq. 6 :

$$
k_{\mathrm{obs}}[\mathrm{MnL}]_{\mathrm{t}}=k_{\mathrm{MnL}}[\mathrm{MnL}]+k_{\mathrm{H}}[\mathrm{MnHL}]+k_{\mathrm{Cu}}[\mathrm{Mn}(\mathrm{L}) \mathrm{Cu}]
$$

where $k_{\mathrm{MnL}}, k_{\mathrm{H}}$, and $k_{\mathrm{Cu}}$ are the rate constants corresponding to the dissociation via spontaneous, proton-assisted and metal-assisted mechanisms, respectively. $K_{\mathrm{MnHL}}$ is the protonation constant of the MnHL intermediate, whereas $K_{\mathrm{MnLCu}}$ corresponds to the stability constant of the dinuclear complex $\operatorname{Mn}(\mathrm{L}) \mathrm{Cu}\left(K_{\mathrm{MnHL}}=[\mathrm{MnHL}] /[\mathrm{MnL}]\left[\mathrm{H}^{+}\right], K_{\mathrm{MnLCu}}=[\mathrm{Mn}(\mathrm{L}) \mathrm{Cu}] /[\mathrm{MnL}][\mathrm{Cu}], k_{1}=k_{\mathrm{H}} \cdot K_{\mathrm{MnHL}}\right.$, and $k_{3}=$ $k_{\mathrm{Cu}} \cdot K_{\mathrm{MnLCu}}$ ). By introducing these expressions into eq. 6 , equation 7 was obtained and then used to analyze the experimental data.

$$
k_{\mathrm{obs}}=\frac{k_{\mathrm{MnL}}+k_{1}\left[\mathrm{H}^{+}\right]+k_{3}\left[\mathrm{Cu}^{\mathrm{II}}\right]}{1+K_{\mathrm{MnHL}}\left[\mathrm{H}^{+}\right]+K_{\mathrm{MnLCu}}\left[\mathrm{Cu}^{\mathrm{II}}\right]}
$$

As a result of the fitting of equation 7 , the rate constant characterizing the spontaneous dissociation $\left(k_{\mathrm{MnL}}\right)$ was found to be very small and affected by a large error, while $k_{3}$, describing the metal-assisted dissociation, was negative. This indicates that the spontaneous and metal-assisted pathways contribute only negligibly to the dissociation of [Mn(4-HET-CDTA) ${ }^{2-}$, justifying to fix the values of the corresponding rate constants to zero in equation 7 . In addition, the protonation constant of the complex determined by $\mathrm{pH}$-potentiometric titration is much lower than the $\mathrm{pH}$ range evaluated in the kinetic study. Thus, the simplified equation 8 was applied for the fitting of the experimental $k_{\mathrm{obs}}$ values.

$$
k_{\mathrm{obs}}=\frac{k_{1}\left[\mathrm{H}^{+}\right]}{1+K_{\mathrm{MnHL}}\left[\mathrm{H}^{+}\right]+K_{\mathrm{MnLCu}}\left[\mathrm{Cu}^{\mathrm{II}}\right]}=\frac{k_{1}\left[\mathrm{H}^{+}\right]}{1+K_{\mathrm{MnLCu}}\left[\mathrm{Cu}^{\mathrm{II}}\right]}
$$

The results of this kinetic data refinement are summarized in Table 3 along with the values for the $\mathrm{Mn}^{\mathrm{II}}$ complexes of CDTA and 1,4-DO2A. The comparison of the $k_{1}$ values for [Mn(4-HET-CDTA)] ${ }^{2-}$ and $[\mathrm{Mn}(\mathrm{CDTA})]^{2-}$ indicates that the presence of the ring substituent in 4-HET-CDTA has a beneficial, although minor, effect on the rate of acid catalyzed dissociation, this being mainly due to the lower ligand basicity. The most relevant comparison of the kinetic inertness of both chelates is based on their half-lives of dissociation, $t_{1 / 2}$, calculated near physiological conditions $(\mathrm{pH}=7.4$, c cuII $=$ 
$1 \times 10^{-5} \mathrm{M}$ ). Based on the $t_{1 / 2}$ values, the $\mathrm{Mn}^{\mathrm{II}}$ complex of 4-HET-CDTA appears to be $\approx 35 \%$ more inert than its non-substituted analogue ( $t_{1 / 2}=16.2 \mathrm{~h}$ versus $12.1 \mathrm{~h}$, respectively). This result may be rationalized in terms of rigidity as the substituent located in 4-position of the cyclohexane ring renders the whole ligand scaffold less flexible. The positive impact of an increased ligand rigidity on the kinetic inertness has already been demonstrated for both $\mathrm{Mn}^{\mathrm{II}}$ and $\mathrm{Gd}^{\mathrm{III}}$ chelates. ${ }^{11,51-53}$

The macrocyclic complex [Mn(1,4-DO2A)], which also dissociates mainly via the proton-assisted pathway, ${ }^{12}$ is characterized by an approx. 3-fold lower $k_{1}$ value than $[\mathrm{Mn}(4-\mathrm{HET}-\mathrm{CDTA})]^{2-}$. As a direct consequence, the calculated half-life of dissociation under physiological conditions, $t_{1 / 2}$, is substantially higher for $[\mathrm{Mn}(1,4-\mathrm{DO} 2 \mathrm{~A})]$ compared to [Mn(4-HET-CDTA $]^{2-}$. Interestingly, 1,4DO2AM (bisamide derivative of 1,4-DO2A; see Chart 1 ) forms an even more inert $\mathrm{Mn}^{\mathrm{II}}$ complex $\left(k_{1}=\right.$ $8.7 \mathrm{M}^{-1} \mathrm{~s}^{-1} ; t_{1 / 2}=556 \mathrm{~h}$ ) thanks to its two non-protonable amide groups which prevent the formation of the monoprotonated intermediate species. ${ }^{4}$ Those results are not unexpected as $\mathrm{Mn}^{\mathrm{II}}$ complexes formed with linear ligands are known to be less inert than their macrocyclic analogues of same denticity. Strictly speaking, CDTA and PyC3A were the only open-chain ligands capable of forming $\mathrm{Mn}^{\mathrm{II}}$ chelates with acceptable kinetic inertness reported so far; 4-HET-CDTA can thus be considered as a novel addition to this rather limited group.

Table 3. Constants and calculated half-lives $\left(t_{1 / 2}=\ln 2 / k_{\mathrm{obs}}, \mathrm{pH}=7.4,\left[\mathrm{Cu}^{\mathrm{II}}\right]=1 \times 10^{-5} \mathrm{M}\right)$ characterizing the dissociation of the $\mathrm{Mn}^{\mathrm{II}}$ complexes formed with 4-HET-CDTA, CDTA and 1,4DO2A $\left(25^{\circ} \mathrm{C}\right)$.

\begin{tabular}{cccc}
\hline & 4-HET-CDTA & \\
\hline$k_{1}\left(\mathrm{M}^{-1} \mathrm{~s}^{-1}\right)$ & $297(8)$ & CDTA $^{[\mathrm{b}]}$ & $1,4-\mathrm{DO}^{2} \mathrm{~A}^{[\mathrm{c}]}$ \\
$k_{2}\left(\mathrm{M}^{-2} \mathrm{~s}^{-1}\right)^{[\mathrm{d}]}$ & - & 400 & 100 \\
$K_{\mathrm{MnLCu}}$ & $53(8)$ & - & $1.6 \times 10^{6}$ \\
$\log K_{\mathrm{MnHL}}{ }^{[\mathrm{e}]}$ & $2.56(5)$ & 79 & - \\
$k_{\text {obs }}\left(\times 10^{-6} \mathrm{~s}^{-1}\right)$ & 11.9 & 2.90 & 4.15 \\
$t_{1 / 2}(\mathrm{~h})$ & 16.2 & 15.9 & 4.0 \\
\hline
\end{tabular}

[a] The data in brackets are the standard deviations; [b] Ref. ${ }^{11}$; [c] ref. ${ }^{12}$; [d] $k_{2}$ is the second-order rate constant, characterizing the proton-assisted dissociation that occurs by the formation of a diprotonated intermediate, $k_{2}=$ $k^{\mathrm{H}}{ }_{\mathrm{MnHL}} \times K_{\mathrm{MnHL}} \times K_{\mathrm{MnH} 2 \mathrm{~L}}$ (with $k^{\mathrm{H}}{ }_{\mathrm{MnHL}}$ being the rate constant of the proton-assisted dissociation of the monoprotonated chelate); [e] determined by $\mathrm{pH}$-potentiometric titration.

\section{${ }^{17} \mathrm{O}$ NMR and ${ }^{1} \mathrm{H}$ NMRD evaluation of the $[\mathrm{Mn}(4-\mathrm{HET}-\mathrm{CDTA})]^{2-}$ complex}


In order to characterize the relaxation properties of the [Mn(4-HET-CDTA $)]^{2-}$ complex and to explain its high relaxivity $\left(r_{1}=4.56 \mathrm{mM}^{-1} \mathrm{~s}^{-1}\right.$ at $20 \mathrm{MHz}$ and $\left.25{ }^{\circ} \mathrm{C}\right)$, nuclear magnetic relaxation dispersion (NMRD) profiles ( $r_{1} v s$. magnetic field strength) were recorded in the frequency range of $10 \mathrm{kHz}-400 \mathrm{MHz}$ at 298, 310 and $323 \mathrm{~K}$ (Fig. 5). As mentioned above, the relaxivity of paramagnetic metal complexes is related to several physico-chemical parameters (e.g. $q, k_{\mathrm{ex}}, \tau_{\mathrm{R}}, T_{1,2 \mathrm{e}}$ ). The independent assessment of some of these is a key issue, therefore NMRD data are often completed with variable-temperature ${ }^{17} \mathrm{O}$ NMR measurements. While the transverse $\left(1 / T_{2}\right)$ and the longitudinal $\left(1 / T_{1}\right){ }^{17} \mathrm{O}$ relaxation rates give access to the water exchange rate $\left(k_{\mathrm{ex}}\right)$ and to the rotational correlation time $\left(\tau_{\mathrm{R}}\right)$, respectively, the ${ }^{17} \mathrm{O}$ chemical shift is related to the number of water molecules directly coordinated to the paramagnetic metal center $(q)$. As shown in Fig. 5, all three NMRD curves have the typical shape of rapidly tumbling, low molecular weight complexes with a single dispersion at 1-10 MHz. The relaxivity of [Mn(4-HET-CDTA) $]^{2-}$ decreases with increasing temperature over the entire frequency range, evidencing that the relaxivity is limited by fast rotation, as was expected.

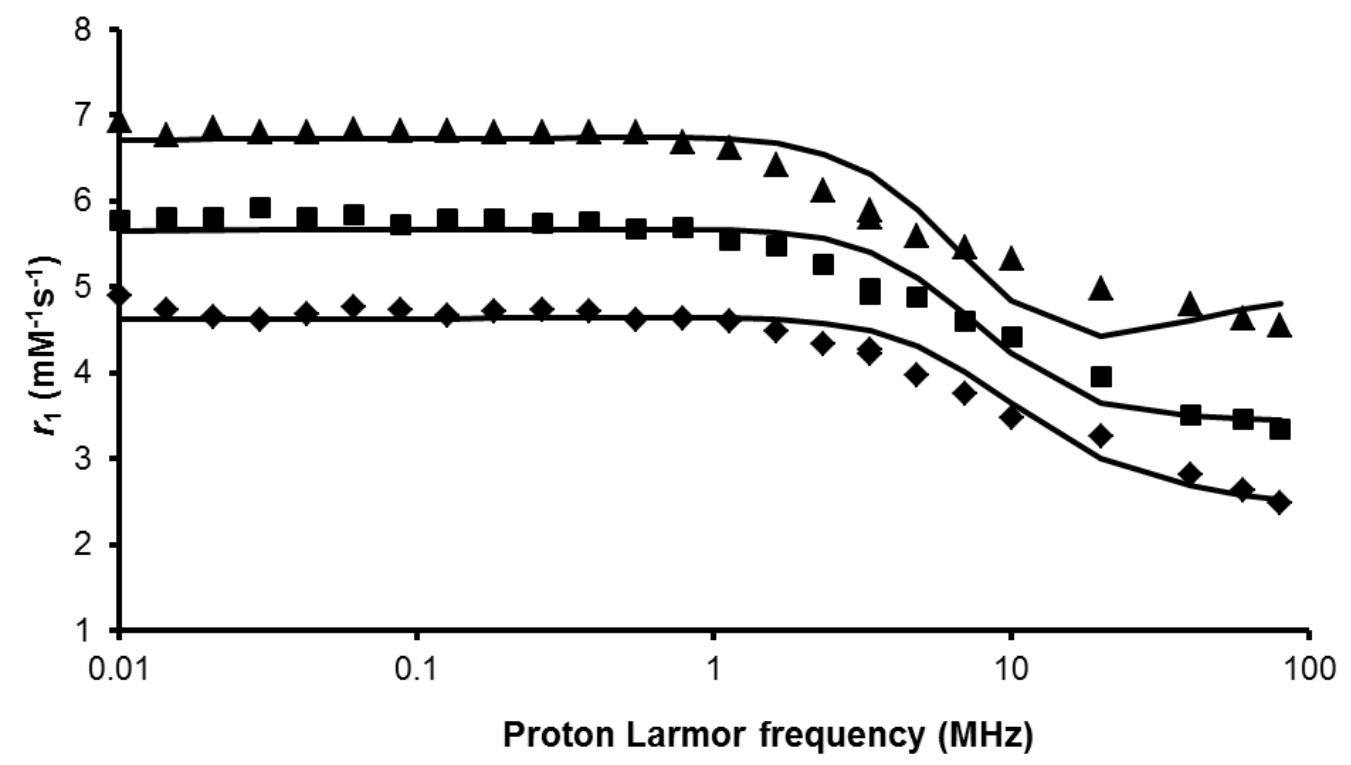

Figure 5. $\quad{ }^{1} \mathrm{H}$ NMRD profiles for $[\mathrm{Mn}(4-\mathrm{HET}-\mathrm{CDTA})]^{2-}(\mathrm{pH}=7.4)$ recorded at $25{ }^{\circ} \mathrm{C}$ (triangles), $37{ }^{\circ} \mathrm{C}$ (squares) and $50^{\circ} \mathrm{C}$ (diamonds).

Information about the water-exchange kinetics was obtained by measuring the ${ }^{17} \mathrm{O}$ relaxation rates for an aqueous [Mn(4-HET-CDTA) $]^{2-}$ solution and a diamagnetic reference at different temperatures (9.4 T, see Fig. 6). As ${ }^{17} \mathrm{O} T_{1}$ values and the chemical shifts showed negligible differences between the $\mathrm{Mn}^{\mathrm{II}}$ complex and the reference, they are not reported. The ${ }^{17} \mathrm{O} 1 / T_{2 \mathrm{r}}$ data have been analyzed using the Swift-Connick equations, assuming a simple exponential behavior of the electron spin relaxation (see ESI for detailed equations). ${ }^{54,55}$ Based on the analogy with $[\mathrm{Mn}(\mathrm{EDTA})]^{2-}$, the hydration number was 
fixed to $q=1$, a value which has also been confirmed experimentally for [Mn(CDTA) $]^{2-} .{ }^{14}$ We would like to mention that we obtain $q=0.81$ using Gale's method to assess $q$ from the maximum value of the transverse ${ }^{17} \mathrm{O}$ relaxation rate. ${ }^{14}$ The fitting procedure allowed the calculation of the water exchange rate, $k_{\mathrm{ex}}{ }^{298}$, its activation enthalpy, $\Delta H^{\ddagger}$, and the electronic relaxation rate of the $\mathrm{Mn}^{\mathrm{II}}$ ion, $1 / T_{1 \mathrm{e}}{ }^{298}$, which are given in Table 4 . The scalar coupling constant, $A_{\mathrm{o}} / \hbar$, was set to $40 \times 10^{6} \mathrm{rad} \mathrm{s}^{-1}$, a value typically obtained experimentally but also by DFT calculations. ${ }^{10}$. From Fig. 6 it appears that the reduced transverse ${ }^{17} \mathrm{O}$ relaxation rates $\left(1 / T_{2 \mathrm{r}}\right)$ obtained for $[\mathrm{Mn}(4-\mathrm{HET}-\mathrm{CDTA})]^{2-}$ are in the fast exchange region above $285 \mathrm{~K}$, while they turn to the intermediate exchange regime below this temperature. The analysis of the ${ }^{17} \mathrm{O}$ NMR data showed that the contribution of the electron spin relaxation term in the overall correlation time $\left(1 / \tau_{\mathrm{c}}=k_{\mathrm{ex}}+1 / T_{1 \mathrm{e}}\right)$ governing the transverse relaxation rate becomes negligible at high temperatures (approx. $3 \%$ ), which ensures the correct determination of the water exchange rate. The maximum contribution of $1 / \mathrm{T}_{1 \mathrm{e}}$ amounts to $30 \%$ at the lowest temperatures and the $1 / \mathrm{T}_{2 \mathrm{r}}$ data cannot be fitted by neglecting the contribution of $\mathrm{T}_{1 \mathrm{e}}$. The $k_{\mathrm{ex}}{ }^{298}$ value obtained for $[\mathrm{Mn}(4-\mathrm{HET}-\mathrm{CDTA})]^{2-}$ is very close to that of $[\mathrm{Mn}(\mathrm{CDTA})]^{2-}$, which is expected considering their identical coordination cage. On the other hand, the water exchange is approximately three times slower than for $[\mathrm{Mn}(\mathrm{EDTA})]^{2-}\left(k_{\mathrm{ex}}{ }^{298}=47.1 \times 10^{7} \mathrm{~s}^{-1}\right)$, most likely due to the more flexible EDTA skeleton which facilitates the rearrangement of the coordination environment during the water exchange process, and about 6-times slower than for the macrocyclic chelate $[\mathrm{Mn}(1,4-\mathrm{DO} 2 \mathrm{~A})]^{10}$ Moreover, the positive value of the activation entropy suggests a dissociatively activated water exchange mechanism. Most importantly, the water exchange of [Mn(4-HET-CDTA) $]^{2-}$ remains fast enough to consider BFMnC $\mathbf{6 a}$ or $\mathbf{6 b}$ for the design of multimeric CAs with optimized relaxivity. ${ }^{22}$

Table 4. Best-fit parameters obtained from the analysis of ${ }^{17} \mathrm{O}$ NMR and ${ }^{1} \mathrm{H}$ NMRD data for the $\mathrm{Mn}^{\mathrm{II}}$ complexes of 4-HET-CDTA, CDTA, EDTA and 1,4-DO2A.

\begin{tabular}{ccccc}
\hline Parameter & 4-HET-CDTA & CDTA $^{[\mathrm{d}]}$ & EDTA $^{[\mathrm{e}]}$ & 1,4-DO2A $^{[\mathrm{f}]}$ \\
\hline$k_{\mathrm{ex}}{ }^{298}\left(\times 10^{7} \mathrm{~s}^{-1}\right)^{[\mathrm{a}]}$ & $17.6 \pm 4.4$ & 14.0 & 47.1 & 113.4 \\
$\Delta H^{\ddagger}\left(\mathrm{kJ} \mathrm{mol}^{-1}\right)^{[\mathrm{a}]}$ & $36.2 \pm 2.8$ & 42.5 & 33.5 & 29.4 \\
$\Delta S^{\ddagger}\left(\mathrm{J} \mathrm{K}^{-1} \mathrm{~mol}^{-1}\right)^{[\mathrm{a}]}$ & $+34 \pm 7$ & - & - & - \\
$A_{\mathrm{O}} / \hbar\left({\left.\mathrm{x} 10^{6} \mathrm{rad} \mathrm{s}^{-1}\right)^{[\mathrm{a}]}}^{4}\right.$ & $40^{[\mathrm{c}]}$ & 4.2 & -40.5 & 43 \\
$1 / T_{1 \mathrm{e}}{ }^{298}\left(\times 10^{7} \mathrm{~s}^{-1}\right)^{[\mathrm{a}]}$ & $7 \pm 2.4$ & 0.65 & - & - \\
$\left.E_{\mathrm{R}}(\mathrm{kJ} \mathrm{mol})^{-1}\right)^{[\mathrm{b}],[\mathrm{h}]}$ & $26.2 \pm 1.4$ & - & 21.8 & 19.1 \\
$\tau_{\mathrm{R}}^{298}(\mathrm{ps})^{[\mathrm{b}]}$ & $104.9 \pm 5.0$ & - & 57 & 46 \\
\hline
\end{tabular}


[a] from ${ }^{17} \mathrm{O}$ NMR fit; [b] from NMRD fit; [c] fixed during the fitting procedure; [d] ref. ${ }^{56}$; [e] ref. ${ }^{57}$; [f] ref. ${ }^{10}$; [h] $E_{\mathrm{R}}$ is the activation energy for the rotational motion of the complex.

To describe the rotational dynamics of the complex, the ${ }^{1} \mathrm{H}$ NMRD data were fitted according to the Solomon-Bloembergen-Morgan (SBM) ${ }^{58}$ and Freed models ${ }^{59}$ characterizing the inner- (IS) and outer-sphere (OS) relaxation mechanisms, respectively, and the Swift-Connick ${ }^{54,55}$ equations describing solvent exchange (see ESI for detailed equations). The water exchange parameters have been set to the values determined by the fitting of the ${ }^{17} \mathrm{O}$ NMR data, while the following parameters were fixed to reasonable estimates: the distance between the metal ion and the inner and outer sphere water protons were set to $r_{\mathrm{MnH}}=2.83 \AA$ and $a_{\mathrm{MnH}}=3.6 \AA$, respectively. ${ }^{10}$; the diffusion coefficient and its activation energy were assigned to $D_{\mathrm{MnH}}=26 \times 10^{-10} \mathrm{~m}^{2} \mathrm{~s}^{-1}$ and $E_{\mathrm{MnH}}=18 \mathrm{~kJ} \mathrm{~mol}^{-1}$; $E_{\mathrm{v}}$ was set to 1 $\mathrm{kJ} \mathrm{mol}^{-1}$. The fit of the NMRD data yielded $\tau_{\mathrm{v}}^{298}=12.2 \mathrm{ps}$ for the correlation time describing the modulation of the ZFS, and $\Delta^{2}=2.3 \times 10^{20} \mathrm{~s}^{-2}$ for the trace of the square of the ZFS tensor. The other best-fit parameters obtained are given in Table 4. Although the quality of the fit is slightly worse for the $25^{\circ} \mathrm{C}$ data at high field than for the lower temperatures, it remains acceptable. The rotational correlation time $\left(\tau_{\mathrm{R}}{ }^{298}\right)$ of $[\mathrm{Mn}(4-\mathrm{HET}-\mathrm{CDTA})]^{2-}$ is longer than those of typical low-molecular-weight complexes without appended groups (e.g. $\approx 84 \%$ increase compared to $[\mathrm{Mn}(\mathrm{EDTA})]^{2-}, \approx 98 \%$ increase versus $[\mathrm{Mn}(1,4-\mathrm{DO} 2 \mathrm{~A})]),{ }^{10}$ which is in agreement with the higher molecular mass of the chelate. This increased $\tau_{\mathrm{R}}{ }^{298}$ value is thus responsible for the remarkably high relaxivity of [Mn(4-HET-CDTA) $]^{2-}$ at $20 \mathrm{MHz}\left(25^{\circ} \mathrm{C}\right)$. 


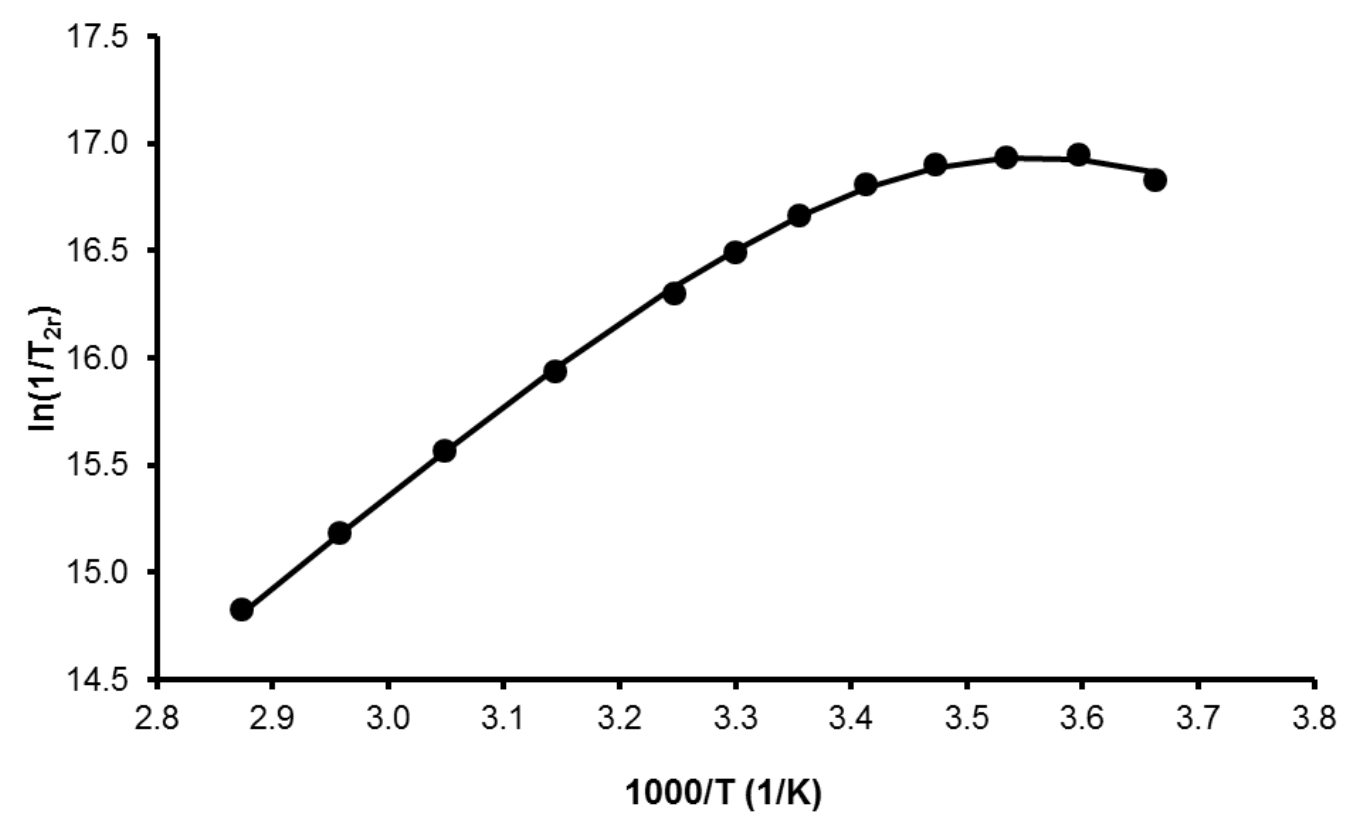

Figure 6. Variable-temperature reduced transverse ${ }^{17} \mathrm{O}$ relaxation rates $\left(1 / T_{2 \mathrm{r}}\right)$ recorded for $[\mathrm{Mn}(4-\mathrm{HET}$ CDTA) $]^{2-}$ at $9.4 \mathrm{~T}$. The solid lines correspond to the best fit of the data.

$\mathrm{Mn}^{\mathrm{II}}$-based imaging probes should ideally possess all of the following three characteristics to allow for efficient in vivo MR or PET/MR imaging: an elevated $T_{1}$-relaxivity for good contrast enhancement, a high thermodynamic stability to ensure that the chelator strongly binds $\mathrm{Mn}^{\mathrm{II}}$ and, especially, a sufficient kinetic inertness to avoid, or at least minimize, complex dissociation prior to excretion from the body. In view of the currently available literature and the data obtained in the present study, 4-HET-CDTA (and most likely all "click"-conjugates derived from $\mathbf{6 a}$ and $\mathbf{6 b}$ ) is among the few $\mathrm{Mn}^{\mathrm{II}}$ chelators that satisfy all of the above requirements. The most relevant data for comparing those few complexes are summarized in Table 5.

Table 5. Relevant relaxometric, thermodynamic and kinetic parameters $\left(25^{\circ} \mathrm{C}\right)$ for comparing $\mathrm{Mn}^{\mathrm{II}}$ complexes of 4-HET-CDTA and other hexadentate chelators reported in the literature.

\begin{tabular}{cccccc}
\hline Parameter & 4-HET-CDTA ${ }^{[\mathrm{a}]}$ & CDTA & PyC3A $^{[\mathrm{b}]}$ & 1,4-DO2A $^{[\mathrm{c}]}$ & 1,4-DO2AM $^{[\mathrm{d}]}$ \\
\hline$r_{1}\left(\mathrm{mM}^{-1} \mathrm{~s}^{-1}\right) 25 / 37$ & $4.56^{[\mathrm{f}]} / 3.43$ & $3.65 / 2.75$ & $3.3 / 2.5$ & $2.1^{[\mathrm{g}]} /-$ & $2.5 /-$ \\
$q$ & 1 & 1 & 1 & $0.87^{[\mathrm{g}]}$ & 0.87 \\
\hline $\log K_{\mathrm{MnL}}$ & 13.80 & 14.32 & 14.14 & 15.68 & 12.64 \\
$\log K_{\mathrm{MnL}}{ }^{\mathrm{pH}=7.4}$ & - & $12.34^{[\mathrm{b}]}$ & 11.34 & $10.10^{[\mathrm{b}]}$ & - \\
$\mathrm{pMn}^{[\mathrm{h}]}$ & 8.62 & 8.68 & 8.17 & 7.27 & 6.98 \\
\hline
\end{tabular}




\begin{tabular}{cccccc}
\hline$t_{1 / 2}(\mathrm{~h})$ & 16.2 & 12.1 & $-{ }^{[i]}$ & 48.3 & 556 \\
\hline BFMnC & $\mathbf{6 a} / \mathbf{6 b}$ & $\mathbf{6 a} / \mathbf{6 b}$ & $t$ Bu-PyC3A-NHS & - & - \\
\hline
\end{tabular}

[a] This work; [b] ref. ${ }^{26}$; [c] ref. ${ }^{12}$; [d] ref. ${ }^{4}$; [e] $20 \mathrm{MHz}$; [f] given the superior molecular weight of 4-HETCDTA, this value cannot be strictly compared with the $r_{1}$ data of other chelates in this table. Nonetheless, for all the "click"-conjugates derived from $\mathbf{6 a} / \mathbf{6 b}$, relaxivities are expected to be higher than for $[\operatorname{Mn}(\mathrm{CDTA})]^{2-}\left(r_{1}>\right.$ $3.65 \mathrm{mM}^{-1} \mathrm{~s}^{-1}$ due to an increase in $\tau_{\mathrm{R}}$ ); [g] ref. ${ }^{10}$; [h] pMn values were calculated by using the approach of É. Tóth et al. $\left(25^{\circ} \mathrm{C}, \mathrm{pH}=7.4\right.$ and $\left.\mathrm{C}_{\mathrm{MnII}}=\mathrm{C}_{\mathrm{L}}=1 \times 10^{-5} \mathrm{M}^{44}\right)$; [i] $[\mathrm{Mn}(\mathrm{PyC} 3 \mathrm{~A})]^{-}$is $\approx 1.6$-fold more inert to $\mathrm{Zn}^{\mathrm{II}}-$ induced transmetallation than $[\mathrm{Mn}(\mathrm{CDTA})]^{2-}$ at $\mathrm{pH} 6.0$ and $37^{\circ} \mathrm{C}$ (no data reported for $\mathrm{pH} 7.4,25^{\circ} \mathrm{C}$ ) ${ }^{26}$

Albeit [Mn(1,4-DO2A)] and, especially, [Mn(1,4-DO2AM) $]^{2+}$ show very promising inertness towards dissociation, they suffer from (i) a reduced hydration number $(q=0.87)$ which negatively impacts the relaxivity, (ii) slower complexation kinetics than open-chain CDTA derivatives (due to the macrocyclic nature), which might be an issue in radiolabeling experiments, (iii) the absence of reported bifunctional derivatives. It should also be mentioned that a group of extremely inert CDTAbisamide-based $\mathrm{Mn}^{\mathrm{II}}$ chelates has been patented recently.$^{60}$ The here described 4-P-CDTA $(t \mathrm{Bu})_{4}$ and 4$\mathrm{A}-\mathrm{CDTA}(\mathrm{Bu})_{4}$ are, along with $t \mathrm{Bu}-\mathrm{PyC} 3 \mathrm{~A}-\mathrm{NHS}$ reported by Caravan et al. ${ }^{26}$ the only rationally designed BFMnCs enabling the in vivo evaluation of $\mathrm{Mn}^{\mathrm{II}}$-based PET/MR tracers.

\section{Conclusions}

In view of designing $\mathrm{Mn}^{\mathrm{II}}$-based MR and PET/MR imaging agents combining the optimal balance of thermodynamic stability, kinetic inertness and elevated relaxivity with targeting or bioresponsive properties, two CuAAC-reactive BFMnCs have been prepared. 4-P-CDTA $(t B u)_{4}(\mathbf{6 a})$ and 4-A$\mathrm{CDTA}(\mathrm{Bu})_{4}(\mathbf{6 b})$, bearing an alkyne/azide substituent on the cyclohexane ring, were obtained via a 6step synthesis involving the build-up of a functionalized trans-1,2-diaminocyclohexane core. To evaluate the potential impact of a triazole-bearing substituent on the physico-chemical properties of the corresponding $\mathrm{Mn}^{\mathrm{II}}$ complex, the model chelator 4-HET-CDTA (8a) was synthesized from $\mathbf{6 a}$. The protonation constants revealed that 4-HET-CDTA is slightly less basic than parent CDTA, most likely due to the weak electron-withdrawing effect of the triazole moiety. As a direct consequence, the thermodynamic stabilitiy of the complexes formed with $\mathrm{Mn}^{\mathrm{II}}$ as well as with essential metal ions $\left(\mathrm{Cu}^{\mathrm{II}}\right.$, $\mathrm{Zn}^{\mathrm{II}}, \mathrm{Ca}^{\mathrm{II}}$ and $\mathrm{Mg}^{\mathrm{II}}$ ) are marginally lower for 4-HET-CDTA compared to CDTA (log $K_{\mathrm{MnL}}=13.80$ versus 14.32, respectively). Nonetheless, the conditional stability of [Mn(4-HET-CDTA) $]^{2-}$ is almost identical to that of $[\mathrm{Mn}(\mathrm{CDTA})]^{2-}$ as demonstrated by the calculated $\mathrm{pMn}$ values (pMn $=8.62$ versus 8.68, respectively). A kinetic investigation of the transmetallation reaction between [Mn(4-HETCDTA) $]^{2-}$ and $\mathrm{Cu}^{\mathrm{II}}$ ions has shown that complex dissociation mainly occurs via a proton-assisted mechanism: here, the reduced basicity of 4-HET-CDTA has a positive impact on the proton-assisted 
dissociation which is slightly slower for $[\mathrm{Mn}(4-\mathrm{HET}-\mathrm{CDTA})]^{2-}$ than for $[\mathrm{Mn}(\mathrm{CDTA})]^{2-}\left(k_{1}=297 \mathrm{vs}\right.$. $400 \mathrm{M}^{-1} \mathrm{~s}^{-1}$, respectively). Most importantly, the dissociation half-life calculated near physiological conditions, which is the best parameter for evaluating the kinetic inertness of a complex, is $\approx 35 \%$ higher for [Mn(4-HET-CDTA)] ${ }^{2-}$ with $t_{1 / 2}=16.2 \mathrm{~h}$ compared to $12.1 \mathrm{~h}$ for [Mn(CDTA)] $]^{2-}$ (pH 7.4, 25 ${ }^{\circ} \mathrm{C}$ ). This may be explained by the combined effects of reduced basicity and increased rigidity of the ligand. As demonstrated by the fitting of ${ }^{17} \mathrm{O}$ NMR data and ${ }^{1} \mathrm{H}$ NMRD profiles, the remarkably high relaxivity of $[\mathrm{Mn}(4-\mathrm{HET}-\mathrm{CDTA})]^{2-}\left(r_{1}=4.56 \mathrm{mM}^{-1} \mathrm{~s}^{-1}\right.$ at $\left.20 \mathrm{MHz}, 25{ }^{\circ} \mathrm{C}\right)$, which evidences the presence of an inner-sphere water $(q=1)$, is due to an increased rotational correlation time $\left(\tau_{\mathrm{R}}{ }^{298}=105\right.$ ps). Additionally, the fast water-exchange is in good agreement with the $k_{\text {ex }}$ value reported for $[\mathrm{Mn}(\mathrm{CDTA})]^{2-}\left(k_{\mathrm{ex}}{ }^{298}=17.6 \times 10^{7}\right.$ vs. $14.0 \times 10^{7} \mathrm{~s}^{-1}$, respectively) given their identical coordination cage.

Compound $6 \mathbf{6}$ is currently employed for the synthesis of a target-specific ${ }^{52 g / 55} \mathrm{Mn}$-conjugate to be evaluated in hybrid imaging experiments.

\section{Experimental section}

\section{Synthesis}

All commercially purchased reagents and solvents were used as received and without further purification. NMR spectra were acquired on a Bruker Avance $600\left(600 \mathrm{MHz}\right.$ for $\left.{ }^{1} \mathrm{H}\right)$ spectrometer and processed/analyzed using MestreNova 8.1 software (Mestrelab Research). High resolution mass spectrometry (HRMS) was performed using a hybrid linear ion trap FT-ICR mass spectrometer LTQFT Ultra (Thermo Fisher Scientific, Bremen, Germany) equipped with a 7 T supra-conducting magnet. The electrospray ionisation (ESI) source was operated in negative or positive mode. Infrared (IR) spectra were measured on a Shimadzu FTIR-8400 Fourier Transform Infrared spectrophotometer (confirmation of the presence of azide functionalities in compounds $\mathbf{2}$ and $\mathbf{6 b}$ ).

\section{4-(((tert-Butyldiphenylsilyl)oxy)methyl)-cyclohexene (1)}

By use of an addition funnel, tert-butyldiphenylsilyl chloride (4.343 g, $15.49 \mathrm{mmol}$ ) in $7 \mathrm{~mL} \mathrm{CH}_{2} \mathrm{Cl}_{2}$ was added dropwise to a solution of 3-cyclohexene-1-methanol (1.688 g, $14.75 \mathrm{mmol}$ ) and imidazole

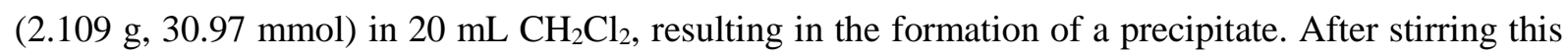
suspension for $18 \mathrm{~h}$ at room temperature $(\mathrm{RT}), \mathrm{CH}_{2} \mathrm{Cl}_{2}$ was added $(30 \mathrm{~mL})$ and the reaction quenched with saturated $\mathrm{NH}_{4} \mathrm{Cl}(30 \mathrm{~mL})$. The layers were separated and the aqueous phase was extracted with $\mathrm{CH}_{2} \mathrm{Cl}_{2}(2 \times 30 \mathrm{~mL})$. The combined organic extracts were washed with brine $(30 \mathrm{~mL})$, dried over $\mathrm{MgSO}_{4}$, filtered and concentrated under reduced pressure. The obtained oily residue was purified by silica gel column chromatography (petroleum ether/EtOAc 99:1, $\mathrm{R}_{\mathrm{f}}=0.84$ ) to yield $\mathbf{1}$ as a colorless oil (5.015 g, $97 \%$ yield). 
${ }^{1} \mathrm{H}$ NMR (600 MHz, $\left.\mathrm{CDCl}_{3}\right) \delta 7.75(\mathrm{dt}, J=7.9,1.6 \mathrm{~Hz}, 4 \mathrm{H}), 7.51-7.41(\mathrm{~m}, 6 \mathrm{H}), 5.74(\mathrm{~d}, J=2.3 \mathrm{~Hz}$, 2H), 3.63 (d, $J=6.1 \mathrm{~Hz}, 2 \mathrm{H}), 2.24-2.04$ (m, 3H), $1.99-1.77$ (m, 3H), $1.43-1.30$ (m, 1H), 1.13 (s, 9H).

${ }^{13} \mathrm{C}$ NMR (151 MHz, $\left.\mathrm{CDCl}_{3}\right) \delta 135.66$ (CH Ar), 134.10 (C Ar), 129.55 (CH Ar), 127.63 (CH Ar), 127.11 \& $126.34(\mathrm{C}=\mathrm{C}), 68.63\left(\mathrm{CH}_{2}\right.$-OTBDPS), 36.41, 28.33, $\left.26.94\left(\mathrm{C}_{(\mathrm{CH}}\right)_{3}\right), 25.43,24.88,19.40$ $\left(\mathrm{C}\left(\mathrm{CH}_{3}\right)_{3}\right)$.

Note: 1 could not be ionized in ESI-MS and thus, not be identified.

\section{4-(((tert-Butyldiphenylsilyl)oxy)methyl)-trans-1,2-diazidocyclohexane (2)}

In a $250 \mathrm{~mL}$ round-bottomed flask, a mixture of alkene 1 (3.323 g, $9.479 \mathrm{mmol}$ ), $\mathrm{NaN}_{3}$ (3.081 g, $47.393 \mathrm{mmol})$ and $\mathrm{Mn}(\mathrm{OAc})_{3} .2 \mathrm{H}_{2} \mathrm{O}$ (7.859 $\mathrm{g}$, 28,437 mmol) was put under argon atmosphere, suspended in a mixture of dry $\mathrm{CH}_{3} \mathrm{CN} / \mathrm{CH}_{2} \mathrm{Cl}_{2}(85: 15,100 \mathrm{~mL})$ and cooled to $-20^{\circ} \mathrm{C}$. After addition of $10 \mathrm{~mL}$ TFA, the reaction was vigorously stirred for $4 \mathrm{~h}$ at -15 to $-20^{\circ} \mathrm{C}$. The reaction was then quenched by adding $\mathrm{NaHSO}_{3}(10 \%, 75 \mathrm{~mL})$ and the aqueous phase was extracted with EtOAc $(3 \mathrm{x} 75$ $\mathrm{mL})$. The combined organic fractions were successively washed with a saturated $\mathrm{Na}_{2} \mathrm{CO}_{3}$ solution $(2 \mathrm{x}$ $70 \mathrm{~mL}$ ) and brine (2 x $70 \mathrm{~mL})$, dried over $\mathrm{MgSO}_{4}$ and evaporated in vacuo. ${ }^{1} \mathrm{H}$ and ${ }^{13} \mathrm{C}$ NMR analysis of the crude oil indicated that the expected trans-diazide, bearing the tertbutyl(methoxy)diphenylsilane group in an axial position, had been formed preferentially (axial/equatorial $\approx 90: 10$ ). The latter was isolated from several impurities as well as from the equatorially-substituted isomer by careful and repeated silica gel column chromatography (petroleum ether/ $\mathrm{Et}_{2} \mathrm{O} 99$ :1). Individual column fractions were tested for purity by TLC (petroleum ether/EtOAc 97:3, $\left.\mathrm{R}_{\mathrm{f}}=0.61\right)$ and combined accordingly. The pure 4-axial trans-diazide 2 was obtained as a yellowish oil (2.254 g, $62 \%$ yield).

Caution: Particular care should be taken when performing this reaction. Handling large amounts of sodium azide may be associated with the exposure to highly toxic $\mathrm{HN}_{3}$, therefore all manipulations should be carried out in a well-ventilated fume hood. Regarding the potential explosion hazard of organic azides, we did not experience any problems with compound 2, neither during the extraction step, nor during evaporation under vacuum at $40^{\circ} \mathrm{C}$.

${ }^{1} \mathrm{H}$ NMR (600 MHz, $\left.\mathrm{CDCl}_{3}\right) \delta 7.66(\mathrm{dt}, J=7.9,1.8 \mathrm{~Hz}, 4 \mathrm{H}), 7.38(\mathrm{~m}, 6 \mathrm{H}), 3.56-3.47\left(\mathrm{~m}, 3 \mathrm{H}, \mathrm{CH}_{2}-\right.$ OTBDPS + CH(2) $\left.\mathrm{N}_{3}\right), 3.44$ (td, $\left.J=6.2,3.6 \mathrm{~Hz}, 1 \mathrm{H}, \mathrm{CH}(1) \mathrm{N}_{3}\right), 1.93$ (q, $\left.J=3.2,2.4 \mathrm{~Hz}, 1 \mathrm{H}\right), 1.80$ (dp, $J=12.9,4.6,4.1 \mathrm{~Hz}, 2 \mathrm{H}), 1.67$ (dt, $J=14.0,6.6,4.2 \mathrm{~Hz}, 1 \mathrm{H}$ ), 1.57 (ddd, $J=13.2,6.6,2.0 \mathrm{~Hz}, 1 \mathrm{H}$ ), 1.49 (dq, $J=7.8,4.1,3.6 \mathrm{~Hz}, 2 \mathrm{H}), 1.07$ (s, 9H).

${ }^{13} \mathrm{C}$ NMR (151 MHz, $\mathrm{CDCl}_{3}$ ) $\delta 135.58$ (CH Ar), 133.58 \& 133.56 (C Ar), 129.74 \& 129.72 (CH Ar), 127.74 \& 127.72 ( $\mathrm{CH} \mathrm{Ar}), 66.64$ ( $\mathrm{CH}_{2}$-OTBDPS), $61.31 \& 59.83$ (2 x $\left.\mathrm{CH}-\mathrm{N}_{3}\right), 34.31,29.15,26.88$ $\left(\mathrm{C}(\mathrm{CH} 3)_{3}\right)$, 25.03, 23.54, $\left.19.28\left(\mathrm{C}_{(\mathrm{CH}}\right)_{3}\right)$.

IR: $v_{\mathrm{N} 3}=2097.66 \mathrm{~cm}^{-1}$ 
Note: 2 could not be ionized in ESI-MS and thus, not be identified. Elemental analysis was not performed due to potential explosion hazard of organic azides.

\section{4-(((tert-Butyldiphenylsilyl)oxy)methyl)-trans-1,2-diaminocyclohexane (3)}

Diazide 2 (1.526 g, $3.51 \mathrm{mmol}$ ) and $481 \mathrm{mg}$ 10\% Pd/C were placed in a $100 \mathrm{~mL}$ round-bottomed flask, suspended in dry EtOAc/MeOH (75:25, $76 \mathrm{~mL})$ and flushed with argon for 10 minutes. The reaction mixture was then hydrogenated at atmospheric pressure and RT for $4 \mathrm{~h}$. After removal of the catalyst by filtration over Celite, the filtrate was evaporated to dryness to yield diamine $\mathbf{3}$ as a slightly yellowish oil (1.344 $\mathrm{g} \approx$ quantitative yield). The obtained diamine was used in the following synthesis step without further purification.

${ }^{1} \mathrm{H}$ NMR (600 MHz, $\left.\mathrm{CDCl}_{3}\right) \delta 7.67$ (m, 4H), 7.46 - 7.34 (m, 6H), 3.66 - 3.58 (m, 2H, $\mathrm{CH}_{2}$-OTBDPS), 2.35 (dt, $J=12.4,6.0 \mathrm{~Hz}, 2 \mathrm{H}, 2$ x $\left.\mathrm{CHNH}_{2}\right), 2.11-1.89$ (m, 5H, $1 \mathrm{H}$ chx +2 x NH$\left.H_{2}\right), 1.89-1.79$ (m, 1H), 1.77 - 1.62 (m, 2H), 1.55 - 1.45 (m, 1H), 1.37 - 1.26 (m, 1H), 1.17 (m, 1H), 1.08 (s, 9H).

${ }^{13} \mathrm{C}$ NMR (151 MHz, $\left.\mathrm{CDCl}_{3}\right) \delta 135.59$ (CH Ar), 133.94 \& 133.92 (C Ar), 129.59 (CH Ar), 127.64 ( $\mathrm{CH} \mathrm{Ar}), 65.59$ ( $\mathrm{CH}_{2}$-OTBDPS), 56.95 \& 52.90 (2 x $\left.\mathrm{CH}-\mathrm{NH}_{2}\right)$, 35.93, 35.35, 29.95, $26.94\left(\mathrm{C}\left(\mathrm{CH}_{3}\right)_{3}\right)$, 25.23, $19.29\left(\mathrm{C}\left(\mathrm{CH}_{3}\right)_{3}\right)$.

HRMS (FT-ICR, positive), m/z: 383.25147 ([M+H] $]^{+}$; calculated for $\mathrm{C}_{23} \mathrm{H}_{35} \mathrm{~N}_{2} \mathrm{OSi}^{+}$: 383.25132).

\section{Tetra-tert-butyl 4-(((tert-butyldiphenylsilyl)oxy)methyl)-trans-1,2-diaminocyclohexane-}

$N, N, N$ ',N'-tetraacetate (4)

Diamine 3 (1.344 g, $3.51 \mathrm{mmol}$ ) and $\mathrm{K}_{2} \mathrm{CO}_{3}(2.911 \mathrm{~g}, 21.07 \mathrm{mmol})$ were introduced into a $250 \mathrm{~mL}$ round-bottomed flask and placed under argon atmosphere. After addition of dry DMF (90 mL) and tert-butyl bromoacetate $(2.644 \mathrm{~mL}, 17.56 \mathrm{mmol})$, the suspension was heated to $50^{\circ} \mathrm{C}$ for approximately $6 \mathrm{~h}$. The reaction mixture was then diluted with EtOAc $(50 \mathrm{~mL})$, the remaining $\mathrm{K}_{2} \mathrm{CO}_{3}$ removed by centrifugation and the filtrate diluted with additional $400 \mathrm{~mL}$ of EtOAc. The obtained organic fraction was then washed with water $(100 \mathrm{~mL})$ and with brine $(2 \times 100 \mathrm{~mL})$. The organic layer was dried over $\mathrm{MgSO}_{4}$ and the solvents evaporated under reduced pressure. Purification of the crude oil was carried out by silica gel column chromatography, eluting first with a $\mathrm{CH}_{2} \mathrm{Cl}_{2} / \mathrm{EtOAc}$ 95:5 mixture containing $1 \% \mathrm{Et}_{3} \mathrm{~N}$, then slowly increasing the EtOAc content up to $15 \%$. Individual column fractions were tested for purity by TLC (petroleum ether/EtOAc 80:20 $+1 \%$ aq. $\mathrm{NH}_{3}, \mathrm{R}_{\mathrm{f}}=0.69$ ) and combined accordingly. Compound 4 was recovered as a yellow-orange oil (1.900 mg, 65\% yield). ${ }^{1} \mathrm{H}$ NMR (600 MHz, $\mathrm{CDCl}_{3}$ ) $\delta 7.58$ (dt, $\left.J=7.9,1.5 \mathrm{~Hz}, 4 \mathrm{H}\right), 7.37-7.25$ (m, 6H), 3.47 - 3.29 (m, $\left.10 \mathrm{H}, 4 \times \mathrm{CH}_{2} \mathrm{CO}_{2}{ }^{t} \mathrm{Bu}+\mathrm{CH}_{2} \mathrm{OTBDPS}\right), 2.88(\mathrm{~m}, 2 \mathrm{H}, 2 \times \mathrm{CH}-\mathrm{N}), 1.94-1.78(\mathrm{~m}, 2 \mathrm{H}$, chx ring protons), 1.70 (m, $1 \mathrm{H}$, chx ring proton), 1.36 (m, $40 \mathrm{H}, 4 \times \mathrm{C}\left(\mathrm{CH}_{3}\right)_{3}+4 \mathrm{chx}$ ring protons), 0.96 (s, 9H, $\left.\mathrm{C}\left(\mathrm{CH}_{3}\right)_{3}\right)$. 
${ }^{13} \mathrm{C}$ NMR (151 MHz, $\left.\mathrm{CDCl}_{3}\right) \delta$ 170.51, $170.49(\mathrm{C}=\mathrm{O}), 134.54(\mathrm{CH} \mathrm{Ar}), 132.89,132.86(\mathrm{C} \mathrm{Ar})$, 128.48, 128.47 ( $\mathrm{CH} \mathrm{Ar}), 126.58$ ( $\mathrm{CH} \mathrm{Ar}), 79.45$ \& $79.43\left(\mathrm{CO}_{2} \mathrm{C}\left(\mathrm{CH}_{3}\right)_{3}\right), 66.49\left(\mathrm{CH}_{2}-\mathrm{OTBDPS}\right), 58.05$ \& $56.50(2$ x $\mathrm{CH}-\mathrm{N}), 53.06 \& 52.87\left(\mathrm{CH}_{2} \mathrm{CO}_{2}{ }^{t} \mathrm{Bu}\right), 34.01,27.12\left(\mathrm{CO}_{2} \mathrm{C}\left(\mathrm{CH}_{3}\right)_{3}\right), 27.06,25.88$ $\left(\mathrm{C}\left(\mathrm{CH}_{3}\right)_{3}\right), 23.57,22.38,18.21\left(\mathrm{C}\left(\mathrm{CH}_{3}\right)_{3}\right)$.

HRMS (FT-ICR, positive), m/z: $839.52353\left([\mathrm{M}+\mathrm{H}]^{+}\right.$; calculated for $\mathrm{C}_{47} \mathrm{H}_{75} \mathrm{~N}_{2} \mathrm{O}_{9} \mathrm{Si}^{+}$: 839.52363), m/z: $861.50456\left([\mathrm{M}+\mathrm{Na}]^{+}\right.$; calculated for $\mathrm{C}_{47} \mathrm{H}_{74} \mathrm{~N}_{2} \mathrm{NaO}_{9} \mathrm{Si}^{+}:$: 861.50558).

Tetra-tert-butyl 4-(hydroxymethyl)-trans-1,2-diaminocyclohexane- $N, N, N^{\prime}, N$ '-tetraacetate (5)

Tetrabutylammonium fluoride (5.66 mL of a $1.0 \mathrm{M}$ solution in THF, $5.66 \mathrm{mmol}$ ) was slowly added under argon atmosphere to an ice-cooled solution of compound 4 (1.900 g, $2.264 \mathrm{mmol})$ in dry THF (25 mL). After $24 \mathrm{~h}$ stirring at RT, the reaction was quenched by addition of a saturated $\mathrm{NH}_{4} \mathrm{Cl}$ solution $(30 \mathrm{~mL})$. EtOAc was then added $(150 \mathrm{~mL})$, the phases separated and the aqueous layer extracted with EtOAc $(3 \times 30 \mathrm{~mL})$. The combined organic fractions were washed with $\mathrm{NaHCO}_{3}$ sat. (50 mL), dried over $\mathrm{MgSO}_{4}$ and evaporated to dryness. Purification of the crude oil was performed by silica gel column chromatography (gradient: $\mathrm{CH}_{2} \mathrm{Cl}_{2} / \mathrm{EtOAc}$ 95:5 + 1\% $\mathrm{Et}_{3} \mathrm{~N}$ to $\mathrm{CH}_{2} \mathrm{Cl}_{2} / \mathrm{EtOAc} \mathrm{85:15}$ $\left.+1 \% \mathrm{Et}_{3} \mathrm{~N}\right)$; individual column fractions were tested for purity by TLC $\left(100 \% \mathrm{EtOAc}, \mathrm{R}_{\mathrm{f}}=0.36\right)$ and combined accordingly. Pure alcohol 5 was recovered as a yellow-orange oil (1.160 g, 85\% yield).

${ }^{1} \mathrm{H}$ NMR (600 MHz, $\left.\mathrm{CDCl}_{3}\right) \delta 3.54-3.40\left(\mathrm{~m}, 10 \mathrm{H}, 4 \times \mathrm{CH}_{2} \mathrm{CO}_{2}{ }^{t} \mathrm{Bu}+\mathrm{CH}_{2} \mathrm{OH}\right), 2.98(\mathrm{~m}, 1 \mathrm{H}, \mathrm{CH}-\mathrm{N})$, 2.85 (m, 1H, CH-N), 2.54 (s, broad, 1H, OH), $2.00-1.80$ (m, 3H, chx ring protons), 1.46 (m, 40H, 4 $\mathrm{x} \mathrm{C}\left(\mathrm{CH}_{3}\right)_{3}+4$ chx ring protons).

${ }^{13} \mathrm{C}$ NMR (151 MHz, $\left.\mathrm{CDCl}_{3}\right) \delta 171.62 \& 171.57(\mathrm{C}=\mathrm{O}), 80.60 \& 80.52\left(\mathrm{CO}_{2} \mathrm{C}\left(\mathrm{CH}_{3}\right)_{3}\right), 65.64$ $\left(\mathrm{CH}_{2} \mathrm{OH}\right), 60.30 \& 57.64(2 \mathrm{x} \quad \mathrm{CH}-\mathrm{N}), 54.07 \& 54.03\left(\mathrm{CH}_{2} \mathrm{CO}_{2}{ }^{t} \mathrm{Bu}\right), 35.23,28.37,28.13$ $\left(\mathrm{CO}_{2} \mathrm{C}\left(\mathrm{CH}_{3}\right)_{3}\right)$, 25.10, 23.89 .

HRMS (FT-ICR, positive), m/z: $601.40583\left([\mathrm{M}+\mathrm{H}]^{+}\right.$; calculated for $\mathrm{C}_{31} \mathrm{H}_{57} \mathrm{~N}_{2} \mathrm{O}_{9}{ }^{+}$: 601.40586), m/z: $623.38780\left([\mathrm{M}+\mathrm{Na}]^{+}\right.$; calculated for $\mathrm{C}_{31} \mathrm{H}_{56} \mathrm{~N}_{2} \mathrm{NaO}_{9}{ }^{+}$: 623.38780).

Tetra-tert-butyl 4-(prop-2-ynyloxymethyl)-trans-1,2-diaminocyclohexane- $N, N, N$ ', $N$ '-tetraacetate, 4-P-CDTA $(t B u)_{4}(6 \boldsymbol{a})$

Alcohol 5 (962 mg, $1.601 \mathrm{mmol}$ ) and activated powdered $4 \AA$ molecular sieves (1.5 g) were suspended in $15 \mathrm{~mL}$ anhydrous $\mathrm{CH}_{2} \mathrm{Cl}_{2}$, placed under argon atmosphere and cooled to $0^{\circ} \mathrm{C}$. To this mixture, a solution of propargyl bromide ( $80 \%$ in toluene, $518 \mu \mathrm{L}, 4.803 \mathrm{mmol}$ ) and cesium hydroxide monohydrate (806.6 mg, $4.803 \mathrm{mmol}$ ) were successively added and the suspension was vigorously stirred. After $30 \mathrm{~min}$, the ice bath was removed and the reaction was left at RT for approximately $18 \mathrm{~h}$. Full consumption of the adduct was verified by TLC (100\% EtOAc). If needed, 2 equivalents of propargyl bromide and $\mathrm{CsOH} . \mathrm{H}_{2} \mathrm{O}$ were added and reacted for a few additional hours. The reaction mixture was then diluted with EtOAc $(15 \mathrm{~mL})$, centrifuged to remove insolubilities, re-diluted with 
EtOAc (70 mL) and washed with brine (2 x $30 \mathrm{~mL})$. Drying over $\mathrm{MgSO}_{4}$ and evaporation yielded a golden-brown oil which was chromatographed over a silica gel column using an elution gradient $\left(\mathrm{CH}_{2} \mathrm{Cl}_{2} / \mathrm{MeOH}\right.$ 99:1 + 0.5\% aq. $\mathrm{NH}_{3}$ to $\mathrm{CH}_{2} \mathrm{Cl}_{2} / \mathrm{MeOH} 95: 5+0.5 \%$ aq. $\left.\mathrm{NH}_{3}\right)$; individual column fractions were tested for purity by TLC $\left(100 \%\right.$ EtOAc, $\mathrm{R}_{\mathrm{f}}=0.79 ; \mathrm{CH}_{2} \mathrm{Cl}_{2} / \mathrm{MeOH} 97: 3+0.5 \%$ aq. $\left.\mathrm{NH}_{3}, \mathrm{R}_{\mathrm{f}}=0.24\right)$ and combined accordingly. Pure 6a was obtained as a golden-yellow oil (767 mg, $75 \%$ yield).

${ }^{1} \mathrm{H}$ NMR (600 MHz, CDCl $) \delta 4.11\left(\mathrm{~d}, J=2.4 \mathrm{~Hz}, 2 \mathrm{H}, \mathrm{CH}_{2}-\mathrm{C} \equiv \mathrm{CH}\right), 3.48(\mathrm{~d}, J=3.7 \mathrm{~Hz}, 8 \mathrm{H}, 4 \mathrm{x}$

$\mathrm{CH}_{2} \mathrm{CO}_{2}{ }^{t} \mathrm{Bu}$ ), $3.42-3.30$ (m, 2H, $\left.\mathrm{CH}_{2}-\mathrm{O}\right), 2.98(\mathrm{~m}, 1 \mathrm{H}, \mathrm{CH}-\mathrm{N}), 2.87$ (m, $\left.1 \mathrm{H}, \mathrm{CH}-\mathrm{N}\right), 2.40$ (t, $J=2.3$

$\mathrm{Hz}, 1 \mathrm{H}, \mathrm{C} \equiv \mathrm{CH}$ ), $2.02-1.90$ (m, $2 \mathrm{H}$, chx ring protons), $1.90-1.81$ (m, $1 \mathrm{H}$, chx ring protons), 1.45 (s, $40 \mathrm{H}, 4 \times \mathrm{C}\left(\mathrm{CH}_{3}\right)_{3}+4 \mathrm{chx}$ ring protons).

${ }^{13} \mathrm{C}$ NMR (151 MHz, $\left.\mathrm{CDCl}_{3}\right) \delta 171.57 \& 171.53(\mathrm{C}=\mathrm{O}), 80.53$ \& $80.52\left(\mathrm{CO}_{2} \mathrm{C}\left(\mathrm{CH}_{3}\right)_{3}\right), 80.12(\mathrm{C} \equiv \mathrm{CH})$, $74.07(\mathrm{C} \equiv \mathrm{CH}), 73.48\left(\mathrm{CH}_{2}-\mathrm{O}\right), 59.87(\mathrm{CH}-\mathrm{N}), 58.16\left(\mathrm{CH}_{2}-\mathrm{C} \equiv \mathrm{CH}\right), 57.73(\mathrm{CH}-\mathrm{N}), 54.03$ \& 53.87 $\left(\mathrm{CH}_{2} \mathrm{CO}_{2}{ }^{t} \mathrm{Bu}\right)$, 32.60, 28.66, $28.15\left(\mathrm{CO}_{2} \mathrm{C}\left(\mathrm{CH}_{3}\right)_{3}\right), 25.31,23.73$.

HRMS (FT-ICR, positive), m/z: $639.42166\left([\mathrm{M}+\mathrm{H}]^{+}\right.$; calculated for $\mathrm{C}_{34} \mathrm{H}_{59} \mathrm{~N}_{2} \mathrm{O}_{9}{ }^{+}$: 639.42151), m/z: $661.40408\left([\mathrm{M}+\mathrm{Na}]^{+}\right.$; calculated for $\left.\mathrm{C}_{34} \mathrm{H}_{58} \mathrm{~N}_{2} \mathrm{NaO}_{9}{ }^{+}: 661.40345\right)$.

Tetra-tert-butyl 4-(azidomethyl)-trans-1,2-diaminocyclohexane- $N, N, N^{\prime}, N$ '-tetraacetate, 4-A-CDTA $(t B u)_{4}(6 \boldsymbol{b})$

Alcohol 5 (190 mg, $0.316 \mathrm{mmol})$ and triethylamine $(110.2 \mu \mathrm{L}, 0.79 \mathrm{mmol})$ in anhydrous $\mathrm{CH}_{2} \mathrm{Cl}_{2}(12$ $\mathrm{mL}$ ) were placed under argon atmosphere and cooled to $0^{\circ} \mathrm{C}$. Methanesulfonyl chloride (48.9 $\mu \mathrm{L}$, $0.632 \mathrm{mmol}$ ) was slowly added to this solution. After $2-3 \mathrm{~h}$ at $0^{\circ} \mathrm{C}$, the reaction mixture was diluted with diethyl ether $(40 \mathrm{~mL})$, washed with water $(20 \mathrm{~mL})$ and brine $(20 \mathrm{~mL})$ and dried over $\mathrm{MgSO}_{4}$. Evaporation in vacuo yielded the crude mesylate $(199 \mathrm{mg}, \approx 0.293 \mathrm{mmol})$ which was further reacted by dissolution in anhydrous DMF (10 mL), addition of $\mathrm{NaN}_{3}(57.1 \mathrm{mg}, 0.879 \mathrm{mmol})$ and stirring at $75^{\circ} \mathrm{C}$ for $24 \mathrm{~h}$. Once the solution was allowed to cool down, diethyl ether was added (50 mL), the reaction mixture was washed with water $(25 \mathrm{~mL})$ and brine $(25 \mathrm{~mL})$ and dried over $\mathrm{MgSO}_{4}$. Crude azide was purified by silica gel column chromatography $\left(\mathrm{CH}_{2} \mathrm{Cl}_{2} / \mathrm{EtOAc} 95: 5+1 \% \mathrm{Et}_{3} \mathrm{~N}\right)$; individual column fractions were tested for purity by TLC (petroleum ether/EtOAc 80:20 $+1 \%$ aq. $\mathrm{NH}_{3}, \mathrm{R}_{\mathrm{f}}=$ 0.48). Finally, $6 \mathbf{b}$ was recovered as a yellowish oil (139 mg, $70 \%$ over 2 steps).

${ }^{1} \mathrm{H}$ NMR (600 MHz, $\mathrm{CDCl}_{3}$ ) $\delta 3.64-3.29\left(\mathrm{~m}, 8 \mathrm{H}, 4 \times \mathrm{CH}_{2} \mathrm{CO}_{2}{ }^{t} \mathrm{Bu}\right), 3.25-3.09\left(\mathrm{~m}, 2 \mathrm{H}, \mathrm{CH}_{2} \mathrm{~N}_{3}\right.$ ), 3.04 (m, 1H, CH-N), $2.94(\mathrm{~m}, 1 \mathrm{H}, \mathrm{CH}-\mathrm{N}), 2.03-1.79(\mathrm{~m}, 3 \mathrm{H}$, chx ring protons), $1.46(\mathrm{~m}, 40 \mathrm{H}, 4 \mathrm{x}$ $\mathrm{C}\left(\mathrm{CH}_{3}\right)_{3}+4$ chx ring protons).

${ }^{13} \mathrm{C} \mathrm{NMR}\left(151 \mathrm{MHz}, \mathrm{CDCl}_{3}\right) \delta 171.47 \& 171.39(\mathrm{C}=\mathrm{O}), 80.68 \& 80.67\left(\mathrm{CO}_{2} \mathrm{C}\left(\mathrm{CH}_{3}\right)_{3}\right), 58.77$ \& 57.22 (2 x CH-N), $56.13\left(\mathrm{CH}_{2} \mathrm{~N}_{3}\right), 54.15 \& 53.98\left(\mathrm{CH}_{2} \mathrm{CO}_{2}{ }^{t} \mathrm{Bu}\right), 32.72$, 28.77, $28.15\left(\mathrm{CO}_{2} \mathrm{C}\left(\mathrm{CH}_{3}\right)_{3}\right)$, 25.67, 23.28.

HRMS (FT-ICR, positive), m/z: $626.41240\left([\mathrm{M}+\mathrm{H}]^{+}\right.$; calculated for $\mathrm{C}_{31} \mathrm{H}_{56} \mathrm{~N}_{5} \mathrm{O}_{8}{ }^{+}:$626.41234). 
IR: $v_{\mathrm{N} 3}=2097.66 \mathrm{~cm}^{-1}$

Tetra-tert-butyl 4-((1-(2-hydroxyethyl)-1H[1,2,3]triazol-4-yl)methoxy)methyl-trans-1,2diaminocyclohexane- $N, N, N$ ', $N$ '-tetraacetate, 4-HET-CDTA(tBu $)_{4}$ (7a)

2-Azidoethanol (107.3 mg, $1.232 \mathrm{mmol}$; synthesized as reported by Lu et al.) ${ }^{61}$, DIPEA (358 $\mu \mathrm{L}$, $2.054 \mathrm{mmol}$ ), 2,6-lutidine (244 $\mu \mathrm{L}, 2.054 \mathrm{mmol})$ and CuI (219.5 mg, $1.130 \mathrm{mmol}$ ) were added successively to a $50 \mathrm{~mL}$ round-bottomed flask containing alkyne 6a (656 mg, $1.027 \mathrm{mmol})$. The flask was put under argon atmosphere, and the reagents were suspended in anhydrous $\mathrm{CH}_{2} \mathrm{Cl}_{2}(25 \mathrm{~mL})$. After $2 \mathrm{~h}$ of vigorous stirring at RT, the reaction mix was diluted with $\mathrm{CH}_{2} \mathrm{Cl}_{2}(25 \mathrm{~mL})$ and washed twice with aq. $10 \% \mathrm{CuSO}_{4} .5 \mathrm{H}_{2} \mathrm{O}(2 \times 10 \mathrm{~mL})$ to get rid of 2,6-lutidine. In order to remove the copper ions chelated by the clicked product, a $0.4 \mathrm{M}$ aqueous DTPA solution (pH 7.1, $25 \mathrm{~mL}$ ) was added to the organic fraction and the heterogeneous mixture was stirred vigorously for 1-2 h. Once the intensely blue aqueous phase was discarded, a fresh $0.4 \mathrm{M}$ DTPA solution (25 mL) was added to the dichloromethane fraction and the resulting mixture was stirred overnight. The organic phase was then dried over $\mathrm{MgSO}_{4}$ and evaporated under vacuum. Purification of the crude oil was performed by silica gel column chromatography $\left(\mathrm{CH}_{2} \mathrm{Cl}_{2} / \mathrm{MeOH} 97: 3+1 \% \mathrm{NH}_{3}\right)$; individual column fractions were tested for purity by TLC $\left(\mathrm{CH}_{2} \mathrm{Cl}_{2} / \mathrm{MeOH} 97: 3+1 \% \mathrm{NEt}_{3}, \mathrm{R}_{\mathrm{f}}=0.30\right)$. 4-HET-CDTA $(t \mathrm{Bu})_{4}(7 a)$ was obtained as a yellow-orange oil (521 $\mathrm{mg}, 70 \%$ yield).

${ }^{1} \mathrm{H}$ NMR $\left(600 \mathrm{MHz}, \mathrm{CDCl}_{3}\right) \delta 7.76(\mathrm{~s}, 1 \mathrm{H}$, triazole $H), 4.72-4.41\left(\mathrm{~m}, 4 \mathrm{H}, \mathrm{HC}=\mathrm{C}-\mathrm{CH}_{2}-\mathrm{O}+\mathrm{N}_{-} \mathrm{CH}_{2}-\right.$ $\mathrm{CH}_{2}-\mathrm{OH}$ ), 4.04 (t, $\left.J=5.0 \mathrm{~Hz}, 2 \mathrm{H}, \mathrm{CH}_{2}-\mathrm{OH}\right), 3.69-3.19\left(\mathrm{~m}, 10 \mathrm{H}, 4 \mathrm{x} \mathrm{CH}_{2} \mathrm{CO}_{2}{ }^{t} \mathrm{Bu}+\mathrm{HC}=\mathrm{C}-\mathrm{CH}_{2}-\mathrm{O}-\right.$ $\mathrm{CH}_{2}$ ), $2.93(\mathrm{~m}, 1 \mathrm{H}, \mathrm{CH}-\mathrm{N}), 2.84(\mathrm{~m}, 1 \mathrm{H}, \mathrm{CH}-\mathrm{N}), 2.09-1.68$ (m, 3H, chx ring protons), 1.45 (s, 40H, 4 $\mathrm{x} \mathrm{C}\left(\mathrm{CH}_{3}\right)_{3}+4 \mathrm{chx}$ ring protons).

${ }^{13} \mathrm{C}$ NMR (151 MHz, CDCl 3 ) $\delta 171.68(\mathrm{C}=\mathrm{O}), 145.46\left(\mathrm{HC}=\mathrm{C}-\mathrm{CH}_{2}-\mathrm{O}\right), 123.68\left(\mathrm{HC}=\mathrm{C}-\mathrm{CH}_{2}-\mathrm{O}\right), 80.66$ $\left(\mathrm{CO}_{2} \mathrm{C}\left(\mathrm{CH}_{3}\right)_{3}\right), 73.93\left(\mathrm{HC}=\mathrm{C}-\mathrm{CH}_{2}-\mathrm{O}-\mathrm{CH}_{2}\right), 64.68\left(\mathrm{HC}=\mathrm{C}-\mathrm{CH}_{2}-\mathrm{O}-\mathrm{CH}_{2}\right), 61.06\left(\mathrm{CH}_{2}-\mathrm{OH}\right), 59.91$ \&

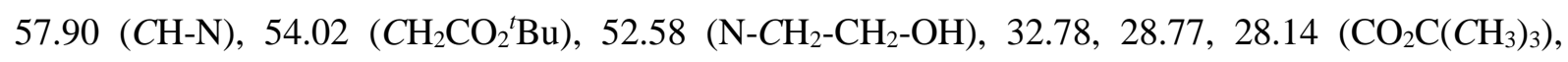
25.38, 23.80 .

HRMS (FT-ICR, positive), m/z: $748.44578\left([\mathrm{M}+\mathrm{Na}]^{+}\right.$; calculated for $\mathrm{C}_{36} \mathrm{H}_{63} \mathrm{~N}_{5} \mathrm{NaO}_{10}{ }^{+}:$748.44671).

4-((1-(2-Hydroxyethyl)-1H[1,2,3]triazol-4-yl)methoxy)methyl-trans-1,2-diaminocyclohexane$N, N, N$ ',N'-tetraacetic acid, 4-HET-CDTA (8a)

7a (363 mg, $0.500 \mathrm{mmol}$ ) was dissolved in a 1:1 TFA/ $\mathrm{CH}_{2} \mathrm{Cl}_{2}$ mixture $(10 \mathrm{~mL})$ and stirred at RT for $18 \mathrm{~h}$. Evaporation of the solvents under reduced pressure yielded an orange oil which was dissolved in $10^{-2} \mathrm{M}$ aq. $\mathrm{HCl}(1.5 \mathrm{~mL}, \mathrm{pH} \approx 2)$ and loaded onto a Dowex 50WX4 (H+ form, 100-200 mesh) cationexchange resin. The latter was washed with water $(200 \mathrm{~mL})$ and the ammonium salt of 8 a was recovered by elution with $0.5 \mathrm{M}$ aq. $\mathrm{NH}_{3}$. The yellow-orange residue obtained after evaporation of solvents was dissolved in $1 \mathrm{M}$ aq. $\mathrm{NH}_{3}(1.2 \mathrm{~mL}, \mathrm{pH} \approx 10)$ and transferred onto a Dowex $1 \mathrm{X} 8$ anion- 
exchange resin ( $\mathrm{Cl}^{-}$form, $100-200$ mesh; before sample loading, the resin was converted to the $\mathrm{OH}^{-}$ form by washing with large volumes of aq. $1 \mathrm{M} \mathrm{NaOH}$ followed by water rinses until neutral $\mathrm{pH}$ of the eluate). After washing of the column with decarbonated water $(200 \mathrm{~mL})$, ligand 8a was eluted using a formic acid gradient $\left(0.005,0.01,0.02,0.04,0.08,0.15,0.3\right.$ and $1 \mathrm{M}$ aq. $\left.\mathrm{HCO}_{2} \mathrm{H}\right)$. Freeze-drying of the fractions containing the desired product $\left(0.15,0.30\right.$ and $1 \mathrm{M}$ aq. $\left.\mathrm{HCO}_{2} \mathrm{H}\right)$ yielded 4-HET-CDTA as an off-white solid (191 mg, 76\% yield).

${ }^{1} \mathrm{H}$ NMR (600 MHz, $\left.\mathrm{D}_{2} \mathrm{O}\right) \delta 8.05$ (s, $1 \mathrm{H}$, triazole $H$ ), $4.58\left(\mathrm{~m}, 2 \mathrm{H}, \mathrm{HC}=\mathrm{C}-\mathrm{CH}_{2}-\mathrm{O}\right), 4.50(\mathrm{t}, J=5.0 \mathrm{~Hz}$, $\left.2 \mathrm{H}, \mathrm{N}-\mathrm{CH}_{2}-\mathrm{CH}_{2}-\mathrm{OH}\right), 4.09-3.36$ (m, $\left.12 \mathrm{H}, 4 \times \mathrm{CH}_{2} \mathrm{CO}_{2}{ }^{\mathrm{B}} \mathrm{Bu}+\mathrm{HC}=\mathrm{C}-\mathrm{CH}_{2}-\mathrm{O}-\mathrm{CH}_{2}+\mathrm{CH}_{2}-\mathrm{OH}\right), 3.24$ (td, $J=11.5,3.6 \mathrm{~Hz}, 1 \mathrm{H}, \mathrm{CH}(2) \mathrm{N}_{3}$ ), 3.09 (td, $\left.J=11.9,3.5 \mathrm{~Hz}, 1 \mathrm{H}, \mathrm{CH}(1) \mathrm{N}_{3}\right), 2.17$ (m, $1 \mathrm{H}$, chx ring proton), 2.07 (m, 1H, chx ring proton), $1.96-1.85$ (m, 1H, chx ring proton), 1.76 (m, 1H, chx ring proton), $1.63-1.30$ (m, 3H, chx ring protons).

${ }^{13} \mathrm{C}$ NMR (151 MHz, $\left.\mathrm{D}_{2} \mathrm{O}\right) \delta 172.25 \& 170.89(\mathrm{C}=\mathrm{O}), 143.46\left(\mathrm{HC}=C-\mathrm{CH}_{2}-\mathrm{O}\right), 125.68\left(\mathrm{HC}=\mathrm{C}-\mathrm{CH}_{2}-\right.$ O), $71.06\left(\mathrm{HC}=\mathrm{C}-\mathrm{CH}_{2}-\mathrm{O}-\mathrm{CH}_{2}\right), 63.42(\mathrm{CH}-\mathrm{N}), 62.44\left(\mathrm{HC}=\mathrm{C}-\mathrm{CH}_{2}-\mathrm{O}-\mathrm{CH}_{2}\right), 59.91\left(\mathrm{CH}_{2}-\mathrm{OH}\right), 58.43$

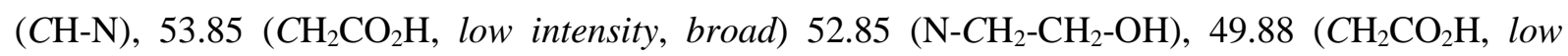
intensity, broad), 31.73, 24.72, 24.63, 19.46.

HRMS (FT-ICR, positive), m/z: $502.21430\left([\mathrm{M}+\mathrm{H}]^{+}\right.$; calculated for $\mathrm{C}_{20} \mathrm{H}_{32} \mathrm{~N}_{5} \mathrm{O}_{10}{ }^{+}$: 502.21437).

\section{Equilibrium studies}

The chemicals ( $\mathrm{MCl}_{2}$ salts) used in the studies were of the highest analytical grade obtained form Sigma-Aldrich and Strem Chemicals Inc. companies. The concentration of the stock solutions was determined by complexometric titration using a standardized $\mathrm{Na}_{2} \mathrm{H}_{2}$ EDTA solution and appropriate indicators (Patton \& Reeder $\left(\mathrm{CaCl}_{2}\right)$, Eriochrome Black $\mathrm{T}\left(\mathrm{MgCl}_{2}\right.$ and $\left.\mathrm{MnCl}_{2}\right)$, xylenol orange $\left(\mathrm{ZnCl}_{2}\right)$, murexid $\left.\left(\mathrm{CuCl}_{2}\right)\right){ }^{62}$

The pH-potentiometric titrations were carried out with a Methrohm 888 Titrando titration workstation, using a Metrohm-6.0233.100 combined electrode. The titrated solutions (6.00 mL) were thermostated at $25{ }^{\circ} \mathrm{C}$, and samples were stirred and kept under inert gas atmosphere $\left(\mathrm{N}_{2}\right)$ to avoid the effect of $\mathrm{CO}_{2}$. The calibration of the electrode was performed by two point calibration $(\mathrm{KH}-\mathrm{phthalate}(\mathrm{pH}=4.005)$ and borax ( $\mathrm{pH}=9.177$ ) buffers). The calculation of $\left[\mathrm{H}^{+}\right]$from the measured $\mathrm{pH}$ values was performed with the use of the method proposed by Irving et al. ${ }^{63}$ by titrating a $0.01 \mathrm{M} \mathrm{HCl}$ solution $(I=0.15 \mathrm{M}$ $\mathrm{NaCl})$ with a standardized $\mathrm{NaOH}$ solution. The differences between the measured $\left(\mathrm{pH}_{\mathrm{read}}\right)$ and calculated $\mathrm{pH}\left(-\log \left[\mathrm{H}^{+}\right]\right)$values were used to obtain the equilibrium $\mathrm{H}^{+}$concentrations from the $\mathrm{pH}-$ data obtained in the titrations. The ion product of water was determined from the same experiment in the $\mathrm{pH}$ range $11.4-12.0$.

The concentration of the 4-HET-CDTA ligand was determined by pH-potentiometric titration, comparing the titration curves obtained in the presence and absence of moderate $\mathrm{Mn}^{2+}$ excess. The protonation constants of 4-HET-CDTA as well as the stability and protonation constants of the 
complexes formed with $\mathrm{Mg}^{\mathrm{II}}, \mathrm{Ca}^{\mathrm{II}}, \mathrm{Mn}^{\mathrm{II}}, \mathrm{Cu}^{\mathrm{II}}$ and $\mathrm{Zn}^{\mathrm{II}}$ were also determined by $\mathrm{pH}$-potentiometric titration. The metal-to-ligand concentration ratios were 1:1 and 2:1 (the concentration of the ligand was generally $2.50-3.00 \mathrm{mM}$ ). The $\mathrm{pH}$-potentiometric titrations curves were measured in the $\mathrm{pH}$ range 1.8 - 11.8 and 86 - $278 \mathrm{~mL} \mathrm{NaOH-pH}$ data pairs were recorded and fitted simultaneously.

The stability constant and solution speciation of the [Mn(4-HET-CDTA) $]^{2-}$ complex was confirmed using ${ }^{1} \mathrm{H}$ relaxometry in order to support the value obtained by $\mathrm{pH}$-potentiometry (for details about $T_{1}$ measurements, see the "Relaxivity determination" section below). $5.00 \mathrm{~mL}$ of a $1.02 \mathrm{mM}$ [Mn(4-HETCDTA) $]^{2-}$ sample were titrated with solid $\mathrm{NaOH}$ or gaseous $\mathrm{HCl}$ (in order to avoid sample dilution) to adjust the $\mathrm{pH}$ in the range $1.75-12.20$, followed by recording and averaging of 4-6 $T_{1}$ values for each $\mathrm{pH}$ data point.

Due to the high conditional stability of $[\mathrm{Cu}(4-\mathrm{HET}-\mathrm{CDTA})]^{2-}$, the formation of the complex was complete (nearly 100\%) even at $\mathrm{pH}=1.73$ (starting point of the $\mathrm{pH}$-potentiometric titration). For this reason, 10 out-of-cell (batch) samples containing a slight excess of ligand and the $\mathrm{Cu}^{\mathrm{II}}$ ion were prepared $\left([\mathrm{Lig}]=3.475 \mathrm{mM},\left[\mathrm{Cu}^{2+}\right]=3.422 \mathrm{mM}, 25{ }^{\circ} \mathrm{C}, 1.0 \mathrm{M}^{2}\left(\mathrm{Na}^{+}+\mathrm{H}^{+}\right) \mathrm{Cl}^{-}\right)$. The samples, whose acidity was varied in the concentration range of $18.8-999 \mathrm{mM}$, were equilibrated for 1 day before recording the absorption spectra at $25{ }^{\circ} \mathrm{C}$ in Peltier thermostated semi-micro $1 \mathrm{~cm}$ Hellma ${ }^{\circledR}$ cells using a Varian CARY 1E, UV-Vis spectrophotometer. The molar absorptivity of the [Cu(4-HET-CDTA)] ${ }^{2-}$ complex was determined at 21 wavelengths ( $800-580 \mathrm{~nm}$ range) by recording the spectra of $1.70 \times 10^{-}$ ${ }^{3}, 2.57 \times 10^{-3}$ and $3.42 \times 10^{-3} \mathrm{M}$ complex solutions, while for the $\mathrm{Cu}^{\mathrm{II}}$ ion, previously published molar absorptivity values (determined under identical conditions) ${ }^{2}$ were used for the data fitting. The molar absorption coefficients of diprotonated [ $\left.\mathrm{CuH}_{2}(4-\mathrm{HET}-\mathrm{CDTA})\right]$ were calculated during the simultaneous data refinement (UV-visible, and $\mathrm{pH}$-potentiometric titration curves obtained at various metal to ligand concentrations). The fitting parameters for the absorbance data are as follows $4.34 \times 10^{-}$ ${ }^{3}, 3.65 \times 10^{-3}, 3.29 \times 10^{-3}, 3.18 \times 10^{-3}, 3.26 \times 10^{-3}, 2.63 \times 10^{-3}, 2.48 \times 10^{-3}, 2.24 \times 10^{-3}, 2.10 \times 10^{-3}, 1.78 \times 10^{-3}$, $1.91 \times 10^{-3}, 1.79 \times 10^{-3}, 2.25 \times 10^{-3}, 2.49 \times 10^{-3}, 2.75 \times 10^{-3}, 2.74 \times 10^{-3}, 2.89 \times 10^{-3}, 2.75 \times 10^{-3}, 2.79 \times 10^{-3}$, $2.76 \times 10^{-3}, 2.58 \times 10^{-3}$, which indicate that the error of the fitting is being kept below $1 \%$ for all wavelengths. The protonation (ligand and complexes) and stability constants (complexes) were calculated from the titration data with the PSEQUAD program. ${ }^{64}$

\section{Kinetic studies}

The dissociation rates of the $[\mathrm{Mn}(4-\mathrm{HET}-\mathrm{CDTA})]^{2-}$ chelate were studied at $25{ }^{\circ} \mathrm{C}$ (Peltier thermostated) and $0.15 \mathrm{M} \mathrm{NaCl}$ ionic strength by monitoring the formation of the $\mathrm{Cu}^{\mathrm{II}}$ complex at 290 $\mathrm{nm}$ via UV-Vis spectrophotometry (Varian CARY 1E instrument) in $1 \mathrm{~cm}$ quartz cuvettes. All dissociation reactions were performed under pseudo-first order conditions where the exchanging metal ion $\left(\mathrm{Cu}^{\mathrm{II}}\right)$ was in $10-40$-fold excess relative to the complex ([complex] $=4.0 \times 10^{-4} \mathrm{M}$, $\mathrm{pH}$ range 4.05 -5.03). The kinetic studies were carried out in a non-coordinating buffer to maintain the $\mathrm{pH}$ in the 
samples constant (0.05 M N,N'-dimethylpiperazine (dmp, $\left.\left.\log K_{2}{ }^{\mathrm{H}}=4.19\right)\right)$. The pseudo-first-order rate constants $\left(k_{\text {obs }}\right)$ were calculated by fitting the absorbance-time data pairs to equation 9:

$$
A_{\mathrm{t}}=\left(A_{\mathrm{g}}-A_{\mathrm{e}}\right) \mathrm{e}^{-\mathrm{kobst}^{\mathrm{t}}}+A_{\mathrm{e}}
$$

where $A_{t}, A_{0}$ and $A_{e}$ are the absorbance at time $t$, at the start and at equilibrium of the reaction, respectively. The calculations were performed with the computer program Micromath Scientist, version 2.0 (Salt Lake City, UT, USA) by using a standard least-squares procedure.

\section{${ }^{17} \mathrm{O}$ NMR and ${ }^{1} \mathrm{H}$ NMRD measurements}

Longitudinal $\left(1 / T_{1}\right)$ and transverse $\left(1 / T_{2}\right){ }^{17} \mathrm{O}$ relaxation rates and chemical shifts of an aqueous solution of $[\mathrm{Mn}(4-\mathrm{HET}-\mathrm{CDTA})]^{2-}(\mathrm{pH}=7.3,3.0 \mathrm{mM})$ and a diamagnetic reference $\left(\mathrm{HClO}_{4}\right.$ acidified water, $\mathrm{pH}=3.3$ ) were measured in the temperature range 273 - $348 \mathrm{~K}$ using a Bruker Avance 400 (9.4 $\mathrm{T}, 54.2 \mathrm{MHz}$ ) spectrometer. The temperature was determined according to previous calibration by means of ethylene glycol and methanol as standards. ${ }^{65} 1 / T_{1}$ and $1 / T_{2}$ values were determined by the inversion-recovery and the Carr-Purcell-Meiboom-Gill spin-echo technique, respectively. ${ }^{66}$ The technique used for the ${ }^{17} \mathrm{O}$ NMR measurements has been described previously. ${ }^{67}$ Susceptibility corrections of the chemical shifts were avoided by placing the sample in a glass sphere fitted into a 10 mm NMR tube. ${ }^{17} \mathrm{O}$ enriched water $\left(10 \% \mathrm{H}_{2}{ }^{17} \mathrm{O}\right.$, CortecNet) was added to the solutions to reach about $1 \%$ enrichment for improving sensitivity. Proton NMRD profiles of the [Mn(4-HET-CDTA) $]^{2-}$ complex $(1.00 \mathrm{mM}, \mathrm{pH}=7.4)$ were recorded in aqueous solution on a Stelar SMARTracer Fast Field Cycling relaxometer $(0.01-10 \mathrm{MHz})$ and a Bruker WP80 NMR electromagnet adapted to variable field measurements $(20-80 \mathrm{MHz})$ and controlled by a SMARTracer PC-NMR console. Temperature monitoring was performed with a VTC91 temperature control unit and maintained by a gas flow. The temperature was determined according to previous calibration with a Pt resistance temperature probe. The least-squares fit of the ${ }^{17} \mathrm{O}$ NMR and of the NMRD data was performed using Visualiseur/Optimiseur (F. Yerly, VISUALISEUR 3.3.7, Lausanne, Switzerland, 2006; F. Yerly, OPTIMISEUR 3.3.7. Lausanne, Switzerland, 2006) running on a MATLAB 8.3.0 (R2014a) platform.

\section{Relaxivity determination}

The longitudinal water proton relaxation rate $\left(r_{1}=1 / T_{1}-1 / T_{\mathrm{w}}\right)$ was measured at $20 \mathrm{MHz}$ with a Bruker Minispec MQ-20 relaxometer (Bruker Biospin, Germany). Samples were thermostated by using a circulating water bath at $25.0 \pm 0.2{ }^{\circ} \mathrm{C}$. The longitudinal relaxation times $\left(T_{1}\right)$ were measured by the inversion-recovery method $\left(180^{\circ}-\tau-90^{\circ}\right)$, averaging 5-6 data points for each concentration point obtained from 14 different $\tau$ values ( $\tau$ values ranging between 0 to at least 6 times the expected $T_{1}$ ). The relaxivity of the complex was determined by titrating a nearly $1.0 \mathrm{mM}$ ligand solution with a $\mathrm{Mn}^{\mathrm{II}}$ stock solution at $\mathrm{pH}=7.32\left(50 \mathrm{mM}\right.$ HEPES buffer, $\left.I=0.15 \mathrm{M} \mathrm{NaCl}, 25{ }^{\circ} \mathrm{C}\right)$. Under these conditions, 
only one $\mathrm{Mn}^{\mathrm{II}}$ ion containing species is present in solution (i.e. the [Mn(4-HET-CDTA) $]^{2-}$ complex, as supported by the $r_{1}$ vs. pH profile). Plotting $1 / T_{1}$ values as a function of [ $\mathrm{Mn}^{\mathrm{II}}$ ] for the samples with [Ligand $]>\left[\mathrm{Mn}^{\mathrm{II}}\right]$ gives a straight line, the slope of which is equal to the relaxivity of the complex.

\section{Acknowledgements}

C.V., H.H.C and B.N. thank the Helmholtz Association for funding of this work through HelmholtzPortfolio Topic “Technology and Medicine”. Part of this research was funded by the Hungarian Scientific Research Fund (OTKA K-120224 project), Le Studium, Loire Valley Institute for Advanced Studies (Gy.T. and F.K.K.) and the János Bolyai Research Scholarship (Gy.T. and F.K.K.) of the Hungarian Academy of Sciences. E.T. acknowledges support of the Ligue contre le cancer (France). The research was also supported by the EU and co-financed by the European Regional Development Fund under the project GINOP-2.3.2-15-2016-00008. The authors are further indebted to Katalin Takács for her help with the pH-potentiometric data collection and Dr. Dezső Szikra for his help with the MS studies. 


\section{References}

1. Drahoš, B.; Lukeš, I.; Tóth, É. Manganese(II) Complexes as Potential Contrast Agents for MRI. European Journal of Inorganic Chemistry 2012, 2012 (12), 1975-1986 DOI: 10.1002/ejic.201101336.

2. Molnár, E.; Camus, N.; Patinec, V.; Rolla, G. A.; Botta, M.; Tircsó, G.; Kálmán, F. K.; Fodor, T.; Tripier, R.; Platas-Iglesias, C. Picolinate-Containing Macrocyclic Mn2+ Complexes as Potential MRI Contrast Agents. Inorganic Chemistry 2014, 53 (10), 5136-5149 DOI: 10.1021/ic500231z.

3. Forgács, A.; Regueiro-Figueroa, M.; Barriada, J. L.; Esteban-Gómez, D.; de Blas, A.; RodríguezBlas, T.; Botta, M.; Platas-Iglesias, C. Mono-, Bi-, and Trinuclear Bis-Hydrated Mn2+ Complexes as Potential MRI Contrast Agents. Inorganic Chemistry 2015, 54 (19), 9576-9587 DOI: 10.1021/acs.inorgchem.5b01677.

4. Forgács, A.; Tei, L.; Baranyai, Z.; Tóth, I.; Zékány, L.; Botta, M. A Bisamide Derivative of [Mn(1,4-DO2A)] - Solution Thermodynamic, Kinetic, and NMR Relaxometric Studies. European Journal of Inorganic Chemistry 2016, 2016 (8), 1165-1174 DOI: 10.1002/ejic.201501415.

5. Grobner, T. Gadolinium - a specific trigger for the development of nephrogenic fibrosing dermopathy and nephrogenic systemic fibrosis? Nephrology Dialysis Transplantation 2006, 21 (4), 1104-1108 DOI: 10.1093/ndt/gfk062.

6. Marckmann, P.; Skov, L.; Rossen, K.; Dupont, A.; Damholt, M. B.; Heaf, J. G.; Thomsen, H. S. Nephrogenic Systemic Fibrosis: Suspected Causative Role of Gadodiamide Used for ContrastEnhanced Magnetic Resonance Imaging. Journal of the American Society of Nephrology 2006, 17 (9), 2359-2362 DOI: 10.1681/asn.2006060601.

7. Kanal, E.; Tweedle, M. F. Residual or Retained Gadolinium: Practical Implications for Radiologists and Our Patients. Radiology 2015, 275 (3), 630-634 DOI: doi:10.1148/radiol.2015150805.

8. Roth, J.; Ponzoni, S.; Aschner, M. In Metallomics and the Cell; Banci, L., Ed.; Springer Netherlands: Dordrecht, 2013; pp 169-201.

9. Drahos, B.; Kubicek, V.; Bonnet, C. S.; Hermann, P.; Lukes, I.; Toth, E. Dissociation kinetics of $\mathrm{Mn2}+$ complexes of NOTA and DOTA. Dalton Transactions 2011, 40 (9), 1945-1951 DOI: 10.1039/CODT01328E.

10. Rolla, G. A.; Platas-Iglesias, C.; Botta, M.; Tei, L.; Helm, L. $1 \mathrm{H}$ and 170 NMR Relaxometric and Computational Study on Macrocyclic Mn(II) Complexes. Inorganic Chemistry 2013, 52 (6), 3268-3279 DOI: 10.1021/ic302785m.

11. Kálmán, F. K.; Tircsó, G. Kinetic Inertness of the Mn2+ Complexes Formed with AAZTA and Some Open-Chain EDTA Derivatives. Inorganic Chemistry 2012, 51 (19), 10065-10067 DOI: 10.1021/ic300832e.

12. Garda, Z.; Forgács, A.; Do, Q. N.; Kálmán, F. K.; Timári, S.; Baranyai, Z.; Tei, L.; Tóth, I.; Kovács, Z.; Tircsó, G. Physico-chemical properties of Mnll complexes formed with cis- and trans-DO2A: thermodynamic, electrochemical and kinetic studies. Journal of Inorganic Biochemistry 2016, 163, 206-213 DOI: http://dx.doi.org/10.1016/j.jinorgbio.2016.07.018.

13. Margerum, D. W.; Pausch, J. B.; Nyssen, G. A.; Smith, G. F. Differential kinetic analysis of the metallic elements. Analytical Chemistry 1969, 41 (2), 233-238 DOI: 10.1021/ac60271a008.

14. Gale, E. M.; Zhu, J.; Caravan, P. Direct Measurement of the Mn(II) Hydration State in Metal Complexes and Metalloproteins through 170 NMR Line Widths. Journal of the American Chemical Society 2013, 135 (49), 18600-18608 DOI: 10.1021/ja4094132.

15. Topping, G. J.; Schaffer, P.; Hoehr, C.; Ruth, T. J.; Sossi, V. Manganese-52 positron emission tomography tracer characterization and initial results in phantoms and in vivo. Medical Physics 2013, 40 (4), 042502/1-042502/8 DOI: doi:http://dx.doi.org/10.1118/1.4793756. 
16. Lewis, C. M.; Graves, S. A.; Hernandez, R.; Valdovinos, H. F.; Barnhart, T. E.; Cai, W.; Meyerand, M. E.; Nickles, R. J.; Suzuki, M. 52Mn Production for PET/MRI Tracking Of Human Stem Cells Expressing Divalent Metal Transporter 1 (DMT1). Theranostics 2015, 5 (3), 227-239.

17. Vanasschen, C.; Brandt, M.; Ermert, J.; Coenen, H. H. Radiolabelling with isotopic mixtures of $52 \mathrm{~g} / 55 \mathrm{Mn}$ (ii) as a straight route to stable manganese complexes for bimodal PET/MR imaging. Dalton Transactions 2016, 45 (4), 1315-1321 DOI: 10.1039/C5DT04270D.

18. de Rosales, R. T. M. Potential clinical applications of bimodal PET-MRI or SPECT-MRI agents. Journal of Labelled Compounds and Radiopharmaceuticals 2014, 57 (4), 298-303 DOI: 10.1002/jlcr.3154.

19. Loving, G. S.; Mukherjee, S.; Caravan, P. Redox-Activated Manganese-Based MR Contrast Agent. Journal of the American Chemical Society 2013, 135 (12), 4620-4623 DOI: 10.1021/ja312610j.

20. Davies, G.-L.; Kramberger, I.; Davis, J. J. Environmentally responsive MRI contrast agents. Chemical Communications 2013, 49 (84), 9704-9721 DOI: 10.1039/C3CC44268C.

21. Frullano, L.; Catana, C.; Benner, T.; Sherry, A. D.; Caravan, P. Bimodal MR-PET Agent for Quantitative pH Imaging. Angewandte Chemie International Edition 2010, 49 (13), 2382-2384 DOI: 10.1002/anie.201000075.

22. Zhu, J.; Gale, E. M.; Atanasova, I.; Rietz, T. A.; Caravan, P. Hexameric MnII Dendrimer as MRI Contrast Agent. Chemistry - A European Journal 2014, 20 (44), 14507-14513 DOI: 10.1002/chem.201403883.

23. Mastarone, D. J.; Harrison, V. S. R.; Eckermann, A. L.; Parigi, G.; Luchinat, C.; Meade, T. J. A Modular System for the Synthesis of Multiplexed Magnetic Resonance Probes. Journal of the American Chemical Society 2011, 133 (14), 5329-5337 DOI: 10.1021/ja1099616.

24. Verwilst, P.; Eliseeva, S. V.; Vander Elst, L.; Burtea, C.; Laurent, S.; Petoud, S.; Muller, R. N.; Parac-Vogt, T. N.; De Borggraeve, W. M. A Tripodal Ruthenium-Gadolinium Metallostar as a Potential av $\beta 3$ Integrin Specific Bimodal Imaging Contrast Agent. Inorganic Chemistry 2012, 51 (11), 6405-6411 DOI: $10.1021 /$ ic300717m.

25. Song, Y.; Kohlmeir, E. K.; Meade, T. J. Synthesis of Multimeric MR Contrast Agents for Cellular Imaging. Journal of the American Chemical Society 2008, 130 (21), 6662-6663 DOI: 10.1021/ja0777990.

26. Gale, E. M.; Atanasova, I. P.; Blasi, F.; Ay, I.; Caravan, P. A Manganese Alternative to Gadolinium for MRI Contrast. Journal of the American Chemical Society 2015, 137 (49), 15548-15557 DOI: $10.1021 /$ jacs.5b10748.

27. Wu, C.; Li, D.; Yang, L.; Lin, B.; Zhang, H.; Xu, Y.; Cheng, Z.; Xia, C.; Gong, Q.; Song, B.; Ai, H. Multivalent manganese complex decorated amphiphilic dextran micelles as sensitive MRI probes. Journal of Materials Chemistry B 2015, 3 (8), 1470-1473 DOI: 10.1039/C4TB02036G.

28. Rostovtsev, V. V.; Green, L. G.; Fokin, V. V.; Sharpless, K. B. A Stepwise Huisgen Cycloaddition Process: Copper(I)-Catalyzed Regioselective "Ligation" of Azides and Terminal Alkynes. Angewandte Chemie International Edition 2002, 41 (14), 2596-2599 DOI: 10.1002/15213773(20020715)41:14<2596::AID-ANIE2596>3.0.CO;2-4.

29. Kolb, H. C.; Finn, M. G.; Sharpless, K. B. Click Chemistry: Diverse Chemical Function from a Few Good Reactions. Angewandte Chemie International Edition 2001, 40 (11), 2004-2021 DOI: 10.1002/1521-3773(20010601)40:11<2004::AID-ANIE2004>3.0.CO;2-5.

30. Vanasschen, C.; Bouslimani, N.; Thonon, D.; Desreux, J. F. Gadolinium DOTA Chelates Featuring Alkyne Groups Directly Grafted on the Tetraaza Macrocyclic Ring: Synthesis, Relaxation Properties, "Click" Reaction, and High-Relaxivity Micelles. Inorganic Chemistry 2011, 50 (18), 89468958 DOI: 10.1021/ic2010997.

31. Baranyai, Z.; Reich, D.; Vagner, A.; Weineisen, M.; Toth, I.; Wester, H.-J.; Notni, J. A shortcut to high-affinity Ga-68 and Cu-64 radiopharmaceuticals: one-pot click chemistry trimerisation on the TRAP platform. Dalton Transactions 2015, 44 (24), 11137-11146 DOI: 10.1039/C5DT00576K. 
32. Mindt, T. L.; Müller, C.; Stuker, F.; Salazar, J.-F.; Hohn, A.; Mueggler, T.; Rudin, M.; Schibli, R. A "Click Chemistry" Approach to the Efficient Synthesis of Multiple Imaging Probes Derived from a Single Precursor. Bioconjugate Chemistry 2009, 20 (10), 1940-1949 DOI: 10.1021/bc900276b.

33. Paulus, A.; Desai, P.; Carney, B.; Carlucci, G.; Reiner, T.; Brand, C.; Weber, W. A. Development of a clickable bimodal fluorescent/PET probe for in vivo imaging. EJNMMI Research 2015, 5 (1), 1-9 DOI: 10.1186/s13550-015-0120-4.

34. Molnár, E.; Váradi, B.; Garda, Z.; Botár, R.; Kálmán, F. K.; Tóth, É.; Tóth, I.; Brücher, E.; Tircsó, G. Remarkable differences and similarities between the isomeric $\mathrm{Mn}(\mathrm{II})$ - cis- and trans-1,2diamionocyclohexane-tetraacetate complexes. Inorg. Chim. Acta 2017, submitted for publication.

35. Snider, B. B.; Lin, H. An Improved Procedure for the Conversion of Alkenes and Glycals to 1,2Diazides Using $\mathrm{Mn}(\mathrm{OAc}) 3 \cdot 2 \mathrm{H} 2 \mathrm{O}$ in Acetonitrile Containing Trifluoroacetic Acid. Synthetic Communications 1998, 28 (10), 1913-1922 DOI: 10.1080/00397919808007024.

36. Burns, C. J.; Daigle, D.; Liu, B.; McGarry, D.; Pevear, D. C.; Trout, R. E. L. New substituted 3amino-3,4-dihydro-2H-1,2-benzoxaborinine-8-carboxylic acid compounds are beta-lactamase inhibitors, useful for treating a subject having bacterial infection such as e.g. upper or lower respiratory tract infection. Patent W02014089365 A1, (WO2014/089365 A1), 2014.

37. Minakawa, M.; Guo, H.-M.; Tanaka, F. Imines that React with Phenols in Water over a Wide pH Range. Journal of Organic Chemistry 2008, 73 (21), 8669-8672 DOI: 10.1021/j08017389.

38. Guo, H.-M.; Minakawa, M.; Ueno, L.; Tanaka, F. Synthesis and evaluation of a cyclic imine derivative conjugated to a fluorescent molecule for labeling of proteins. Bioorganic \& Medicinal Chemistry Letters 2009, 19 (4), 1210-1213 DOI: http://dx.doi.org/10.1016/j.bmcl.2008.12.071.

39. Galanski, M.; Yasemi, A.; Slaby, S.; Jakupec, M. A.; Arion, V. B.; Rausch, M.; Nazarov, A. A.; Keppler, B. K. Synthesis, crystal structure and cytotoxicity of new oxaliplatin analogues indicating that improvement of anticancer activity is still possible. European Journal of Medicinal Chemistry 2004, 39 (8), 707-714 DOI: http://dx.doi.org/10.1016/i.ejmech.2004.04.003.

40. Habala, L.; Dworak, C.; Nazarov, A. A.; Hartinger, C. G.; Abramkin, S. A.; Arion, V. B.; Lindner, W.; Galanski, M.; Keppler, B. K. Methyl-substituted trans-1,2-cyclohexanediamines as new ligands for oxaliplatin-type complexes. Tetrahedron 2008, 64 (1), 137-146 DOI: http://dx.doi.org/10.1016/i.tet.2007.10.069.

41. Dueno, E. E.; Chu, F.; Kim, S.-I.; Jung, K. W. Cesium promoted O-alkylation of alcohols for the efficient ether synthesis. Tetrahedron Letters 1999, 40 (10), 1843-1846 DOI: http://dx.doi.org/10.1016/S0040-4039(99)00083-0.

42. Elliott, P. I. P. In Organometallic Chemistry: Volume 39; The Royal Society of Chemistry: 2014; Vol. 39, pp 1-25.

43. Stasiuk, G. J.; Lowe, M. P. Click chemistry with lanthanide complexes: a word of caution. Dalton Transactions 2009, (44), 9725-9727 DOI: 10.1039/B918891F.

44. Drahoš, B.; Kotek, J.; Hermann, P.; Lukeš, I.; Tóth, E. v. Mn2+ Complexes with PyridineContaining 15-Membered Macrocycles: Thermodynamic, Kinetic, Crystallographic, and 1H/170 Relaxation Studies. Inorganic Chemistry 2010, 49 (7), 3224-3238 DOI: 10.1021/ic9020756.

45. Chen, M.; Reid, R. S. Solution speciation in the aqueous $\mathrm{Na}(\mathrm{I})$-EDTA and $\mathrm{K}(\mathrm{I})$-EDTA systems. Canadian Journal of Chemistry 1993, 71 (5), 763-768 DOI: 10.1139/v93-100.

46. Carr, J. D.; Swartzfager, D. G. Complexometric titration for the determination of sodium ion. Analytical Chemistry 1970, 42 (11), 1238-1241 DOI: 10.1021/ac60293a025.

47. Delgado, R.; da Silva, J. J. R. F. Metal complexes of cyclic tetra-azatetra-acetic acids. Talanta 1982, 29 (10), 815-822 DOI: http://dx.doi.org/10.1016/0039-9140(82)80251-8.

48. Cersosimo, M. G.; Koller, W. C. The diagnosis of manganese-induced parkinsonism. NeuroToxicology 2006, 27 (3), 340-346 DOI: http://dx.doi.org/10.1016/i.neuro.2005.10.006.

49. Sherry, A. D.; Caravan, P.; Lenkinski, R. E. A primer on gadolinium chemistry. Journal of magnetic resonance imaging : JMRI 2009, 30 (6), 1240-1248 DOI: 10.1002/jmri.21966. 
50. Kasprzyk, S. P.; Wilkins, R. G. Kinetics of interaction of metal ions with two tetraazatetraacetate macrocycles. Inorganic Chemistry 1982, 21 (9), 3349-3352 DOI: 10.1021/ic00139a018.

51. Tircsó, G.; Regueiro-Figueroa, M.; Nagy, V.; Garda, Z.; Garai, T.; Kálmán, F. K.; EstebanGómez, D.; Tóth, É.; Platas-Iglesias, C. Approaching the Kinetic Inertness of Macrocyclic Gadolinium(III)-Based MRI Contrast Agents with Highly Rigid Open-Chain Derivatives. Chemistry - A European Journal 2016, 22 (3), 896-901 DOI: 10.1002/chem.201503836.

52. Bonnet, C. S.; Laine, S.; Buron, F.; Tircsó, G.; Pallier, A.; Helm, L.; Suzenet, F.; Tóth, É. A Pyridine-Based Ligand with Two Hydrazine Functions for Lanthanide Chelation: Remarkable Kinetic Inertness for a Linear, Bishydrated Complex. Inorganic Chemistry 2015, 54 (12), 5991-6003 DOI: 10.1021/acs.inorgchem.5b00804.

53. Gale, E. M.; Kenton, N.; Caravan, P. [Gd(CyPic3A)(H2O)2]-: a stable, bis(aquated) and highrelaxivity Gd(iii) complex. Chemical Communications 2013, 49 (73), 8060-8062 DOI: 10.1039/C3CC44116D.

54. Swift, T. J.; Connick, R. E. NMR-Relaxation Mechanisms of 017 in Aqueous Solutions of Paramagnetic Cations and the Lifetime of Water Molecules in the First Coordination Sphere. Journal of Chemical Physics 1962, 37 (2), 307-320 DOI: 10.1063/1.1701321.

55. Swift, T. J.; Connick, R. E. Erratum: NMR-Relaxation Mechanisms of 170 in Aqueous Solutions of Paramagnetic Cations and the Lifetime of Water Molecules in the First Coordination Sphere. Journal of Chemical Physics 1964, 41 (8), 2553-2554 DOI: 10.1063/1.1726303.

56. Maigut, J.; Meier, R.; Zahl, A.; van Eldik, R. Effect of Chelate Dynamics on Water Exchange Reactions of Paramagnetic Aminopolycarboxylate Complexes. Inorganic Chemistry 2008, 47 (13), 5702-5719 DOI: 10.1021/ic702421z.

57. Esteban-Gomez, D.; Cassino, C.; Botta, M.; Platas-Iglesias, C. 170 and $1 \mathrm{H}$ relaxometric and DFT study of hyperfine coupling constants in [Mn(H2O)6]2+. RSC Advances 2014, 4 (14), 7094-7103 DOI: 10.1039/C3RA45721D.

58. Bloembergen, N.; Morgan, L. O. Proton Relaxation Times in Paramagnetic Solutions. Effects of Electron Spin Relaxation. Journal of Chemical Physics 1961, 34 (3), 842-850 DOI: 10.1063/1.1731684.

59. Freed, J. H. Dynamic effects of pair correlation functions on spin relaxation by translational diffusion in liquids. II. Finite jumps and independent T1 processes. Journal of Chemical Physics 1978, 68 (9), 4034-4037 DOI: 10.1063/1.436302.

60. Baranyai, Z.; Garda, Z.; Kalman, F. K.; Krusper, L.; Tircso, G.; Tóth, I.; Ghiani, S.; Maiocchi, A. Ethylenediaminetetraacetic acid bis(amide) derivatives and their respective complexes with $\mathrm{Mn}$ (II) ion for use as MRI contrast agent. Patent WO 2016/135234 A1, (WO 2016/135234 A1), 2016.

61. Lu, X.; Bittman, R. Synthesis of a Photoactivatable (2S,3R)-Sphingosylphosphorylcholine Analogue. Journal of Organic Chemistry 2005, 70 (12), 4746-4750 DOI: 10.1021/jo050513u.

62. Schwarzenbach, G.; Flaschka, H. A. Complexometric titrations. Barnes \& Noble: 1969.

63. Irving, H. M.; Miles, M. G.; Pettit, L. D. A study of some problems in determining the stoicheiometric proton dissociation constants of complexes by potentiometric titrations using a glass electrode. Analytica Chimica Acta 1967, 38, 475-488 DOI: http://dx.doi.org/10.1016/S00032670(01)80616-4.

64. Zekany, L.; Nagypal, I. In Computational Methods for the Determination of Formation Constants; Leggett, D. J., Ed.; Springer US: Boston, MA, 1985; pp 291-353.

65. Raiford, D. S.; Fisk, C. L.; Becker, E. D. Calibration of methanol and ethylene glycol nuclear magnetic resonance thermometers. Analytical Chemistry 1979, 51 (12), 2050-2051 DOI: 10.1021/ac50048a040.

66. Meiboom, S.; Gill, D. Modified Spin-Echo Method for Measuring Nuclear Relaxation Times. Review of Scientific Instruments 1958, 29 (8), 688-691 DOI: 10.1063/1.1716296.

67. Micskei, K.; Helm, L.; Brucher, E.; Merbach, A. E. Oxygen-17 NMR study of water exchange on gadolinium polyaminopolyacetates [Gd(DTPA)(H2O)]2- and [Gd(DOTA)(H2O)]- related to NMR imaging. Inorganic Chemistry 1993, 32 (18), 3844-3850 DOI: 10.1021/ic00070a013. 


\section{For Table of Contents Only}

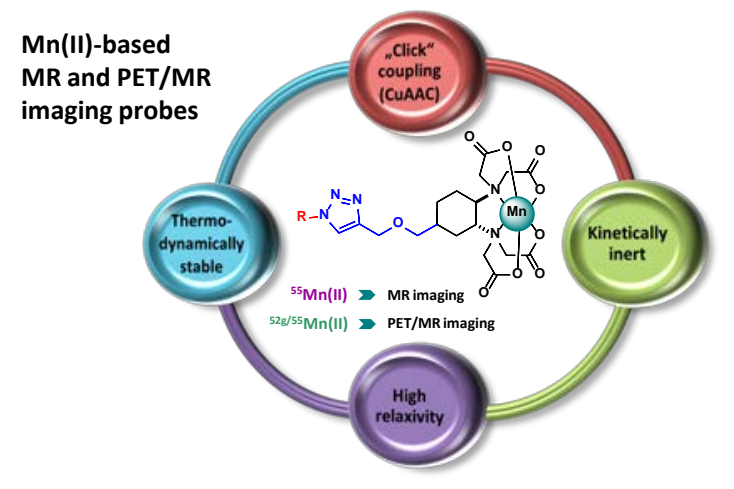

\section{Synopsis}

The synthesis of two CDTA-based bifunctional $\mathrm{Mn}^{\mathrm{II}}$ chelators (BFMnCs) reactive in "click" chemistry is reported. A "click"-conjugate of one BFMnC was used to perform a detailed thermodynamic, kinetic and relaxometric assessment of the corresponding $\mathrm{Mn}^{\mathrm{II}}$ complex. As demonstrated by the exquisite balance between thermodynamic stability, kinetic inertness and relaxivity of the chelate, the reported BFMnCs are promising precursors for $\mathrm{Mn}^{\mathrm{II}}$-based PET/MR tracers $\left({ }^{52 / 55} \mathrm{Mn}^{\mathrm{II}}\right)$ as well as MR contrast agents $\left(\mathrm{Mn}^{\mathrm{II}}\right)$ of the next-generation. 